\title{
GOCI Yonsei Aerosol Retrieval (YAER) algorithm and validation during the DRAGON-NE Asia 2012 campaign
}

\author{
Myungje Choi ${ }^{1}$, Jhoon Kim ${ }^{1}$, Jaehwa Lee ${ }^{2,3}$, Mijin Kim ${ }^{1}$, Young-Je Park ${ }^{4}$, Ukkyo Jeong ${ }^{1}$, Woogyung Kim ${ }^{1}$, \\ Hyunkee Hong ${ }^{5}$, Brent Holben ${ }^{3}$, Thomas F. Eck ${ }^{3,6}$, Chul H. Song ${ }^{7}$, Jae-Hyun Lim ${ }^{8}$, and Chang-Keun Song ${ }^{8}$ \\ ${ }^{1}$ Department of Atmospheric Sciences, Yonsei University, Seoul, Republic of Korea \\ ${ }^{2}$ Earth System Science Interdisciplinary Center, University of Maryland, College Park, MD, USA \\ ${ }^{3}$ NASA Goddard Space Flight Center, Greenbelt, MD, USA \\ ${ }^{4}$ Korea Ocean Satellite Center, Korea Institute of Ocean Science and Technology, Ansan, Republic of Korea \\ ${ }^{5}$ Department of Spatial Information Engineering, Pukyong National University, Busan, Republic of Korea \\ ${ }^{6}$ Universities Space Research Association, Columbia, MD, USA \\ ${ }^{7}$ School of Environmental Science and Engineering, Gwangju Institute of Science and \\ Technology (GIST), Gwangju, Republic of Korea \\ ${ }^{8}$ National Institute of Environmental Research (NIER), Incheon, Republic of Korea
}

Correspondence to: Jhoon Kim (jkim2@yonsei.ac.kr)

Received: 22 July 2015 - Published in Atmos. Meas. Tech. Discuss.: 15 September 2015

Revised: 16 January 2016 - Accepted: 2 March 2016 - Published: 1 April 2016

\begin{abstract}
The Geostationary Ocean Color Imager (GOCI) onboard the Communication, Ocean, and Meteorological Satellite (COMS) is the first multi-channel ocean color imager in geostationary orbit. Hourly GOCI top-of-atmosphere radiance has been available for the retrieval of aerosol optical properties over East Asia since March 2011. This study presents improvements made to the GOCI Yonsei Aerosol Retrieval (YAER) algorithm together with validation results during the Distributed Regional Aerosol Gridded Observation Networks - Northeast Asia 2012 campaign (DRAGONNE Asia 2012 campaign). The evaluation during the spring season over East Asia is important because of high aerosol concentrations and diverse types of Asian dust and haze. Optical properties of aerosol are retrieved from the GOCI YAER algorithm including aerosol optical depth (AOD) at $550 \mathrm{~nm}$, fine-mode fraction (FMF) at $550 \mathrm{~nm}$, single-scattering albedo (SSA) at $440 \mathrm{~nm}$, Ångström exponent (AE) between 440 and $860 \mathrm{~nm}$, and aerosol type. The aerosol models are created based on a global analysis of the Aerosol Robotic Networks (AERONET) inversion data, and covers a broad range of size distribution and absorptivity, including nonspherical dust properties. The Cox-Munk ocean bidirectional reflectance distribution function (BRDF) model is used over ocean, and an improved minimum reflectance technique is
\end{abstract}

used over land. Because turbid water is persistent over the Yellow Sea, the land algorithm is used for such cases. The aerosol products are evaluated against AERONET observations and MODIS Collection 6 aerosol products retrieved from Dark Target (DT) and Deep Blue (DB) algorithms during the DRAGON-NE Asia 2012 campaign conducted from March to May 2012. Comparison of AOD from GOCI and AERONET resulted in a Pearson correlation coefficient of 0.881 and a linear regression equation with GOCI $\mathrm{AOD}=1.083 \times$ AERONET AOD -0.042 . The correlation between GOCI and MODIS AODs is higher over ocean than land. GOCI AOD shows better agreement with MODIS DB than MODIS DT. The other GOCI YAER products (AE, FMF, and SSA) show lower correlation with AERONET than AOD, but still show some skills for qualitative use.

\section{Introduction}

Aerosols have an important role in the Earth's climate system, influencing climate directly through scattering and absorbing radiation, and indirectly by acting as cloud condensation nuclei (IPCC, 2013). Both ground-based and satellite measurements show an increasing trend of aerosol op- 
tical depth (AOD) over East Asia (IPCC, 2013; Hsu et al., 2012; Yoon et al., 2014). In particular, the increasing trend over Asia is strongest during the dry seasons from December to May. Furthermore, aerosol types over East Asia are more complex than over other regions (J. Kim et al., 2007; Lee et al., 2010a). To quantify its impact on climate, accurate observation of aerosol over a broad area is required.

Aerosol can be detected by remote sensing from groundbased and satellite measurement. AERONET (Aerosol Robotic Networks) is the representative global network of ground-based sun photometers, with an absolute observation uncertainty for a single AOD measurement of \pm 0.01 (Holben et al., 1998; Eck et al., 1999). Satellite observations from low earth orbit (LEO) and geostationary earth orbit (GEO) allow detection of aerosol properties over a wider area. Many aerosol retrieval algorithms have been developed and improved using multi-channel sensors in LEO such as the Moderate Resolution Imaging Spectroradiometer (MODIS), Sea-viewing Wide Field-of-View Sensor (SeaWiFS), Medium Resolution Imaging Spectrometer (MERIS), Ozone Monitoring Instrument (OMI), and Visible Infrared Imaging Radiometer Suite (VIIRS) (Higurashi and Nakajima, 1999; J. Kim et al., 2007; Hsu et al., 2006, 2013; Jackson et al., 2013; Kaufman et al., 1997a; Levy et al., 2007, 2013; Remer et al., 2005; Sayer et al., 2012; Torres et al., 1998, 2007, 2012; von Hoyningen-Huene et al., 2011). Multi-channel observations from LEO give global coverage at high accuracy but with the disadvantage of low temporal resolution. The uncertainty in the retrieved AOD from MODIS is reported as $\pm(0.03+5 \%)$ over ocean and $\pm(0.05$ $+15 \%$ ) over land (Remer et al., 2008; Levy et al., 2010). Aerosol retrieval algorithms have also been developed using meteorological imagers aboard GEO satellites, such as the Geostationary Operational Environmental Satellite (GOES), Geostationary Meteorological Satellite (GMS), and Multifunction Transport Satellite (MTSAT) (Kim et al., 2008; Knapp et al., 2002; Wang et al., 2003; Yoon et al., 2007; Urm and Sohn, 2005). These sensors provide observations at a higher temporal resolution than LEO sensors, but have fixed observation area and lower accuracy due to the wider spectral bands and fewer visible channels. The magnitude of the uncertainty in the retrieved AOD using GOES has been reported as \pm 0.13 (Knapp et al., 2005). Despite the extensive observations to date, the confidence level of satellite-based globally averaged AOD trends is still "low" (IPCC, 2013).

The Geostationary Ocean Color Imager (GOCI) onboard the Communication, Ocean, and Meteorological Satellites (COMS) is the first multi-channel visible- and near-infraredwavelength sensor in GEO (Ahn et al., 2012; Choi et al., 2012; Kang et al., 2006). The wavelength bands of the eight channels are centered at 412, 443, 490, 555, 660, 680, 745, and $865 \mathrm{~nm}$, similar to other ocean color sensors such as the Coastal Zone Color Scanner (CZCS), SeaWiFS, MERIS, and MODIS, but GOCI has a high spatial resolution of $500 \mathrm{~m}$ $\times 500 \mathrm{~m}$ (Table 1). It observes East Asia hourly during the daytime, a total of eight times per day. A prototype of the GOCI Yonsei Aerosol Retrieval (YAER) algorithm was developed (Lee et al., 2010b) and is improved in this study to include dynamic (changing with AOD) and nonspherical aerosol models as introduced in Lee et al. (2012). Aerosol optical properties (AOPs) such as aerosol optical depth, size information, and absorptivity can be retrieved hourly from the GOCI YAER algorithm with spatial resolution of $6 \mathrm{~km} \times 6 \mathrm{~km}$. The high temporal information on AOPs over East Asia from GOCI is expected to help understand the diurnal variation of aerosol properties and improve the accuracy of air quality modeling (Park et al., 2014; Saide et al., 2014; $\mathrm{Xu}$ et al., 2015).

The Distributed Regional Aerosol Gridded Observation Networks - Northeast Asia 2012 campaign (DRAGON-NE Asia 2012 campaign) took place in Korea and Japan from 1 March to 31 May to observe aerosol properties and their variability using a dense network of ground-based sun photometers. The campaign provides a data set for validation of aerosol retrieval algorithms in high spatial resolution.

This study introduces the improvements made to the GOCI YAER algorithm and validation results during the DRAGON-NE Asia 2012 campaign. Because MODIS data were used for the prototype algorithm before the launch of GOCI, this study is the first to use real GOCI data. The GOCI YAER products are validated with AERONET data from 38 sites during the DRAGON-NE Asia 2012 campaign. Intercomparison of AOPs between GOCI and MODIS Collection 6 (C6) is also performed for the same period.

In Sect. 2, the improvements of the GOCI YAER algorithm are summarized. In Sect. 3, some aerosol event cases are analyzed using products from the improved algorithm. In Sect. 4, the GOCI YAER products are validated with AERONET and MODIS. In Sect. 5, an error analysis of GOCI YAER AOD against AERONET AOD is presented. Section 6 provides a summary and conclusions.

\section{Improvements of the GOCI YAER algorithm}

Since the distribution of GOCI Level 1B (L1B) radiation data in March 2011, the GOCI YAER algorithm has been updated to process the real GOCI data and to improve the data quality. Figure 1 shows the flowchart for the GOCI YAER algorithm. The improvements made to the algorithm as compared to described in Lee et al. (2010b) will be discussed according to the sequence shown in the flowchart. The algorithm uses topof-atmosphere (TOA) reflectance $\left(\rho_{\mathrm{TOA}}\right)$ as input data,

$\rho_{\mathrm{TOA}}(\lambda)=\frac{\pi \cdot L(\lambda)}{\mu_{0} \cdot E_{0}(\lambda)}$,

where $\lambda$ is the wavelength of each GOCI channel $(412,443$, $490,555,660,680,745$, and $865 \mathrm{~nm}), L(\lambda)$ is the observed radiance from GOCI, $\mu_{0}$ is the cosine of the solar zenith angle $\left(\theta_{0}\right)$, and $E_{0}$ is the extraterrestrial solar flux. 
Table 1. The specification of ocean color sensors.

\begin{tabular}{|c|c|c|c|c|c|}
\hline Sensor & CZCS & SeaWiFS & MERIS & MODIS & GOCI \\
\hline Platform & Nimbus-7 & OrbView-2 & Envisat & Terra/Aqua & COMS \\
\hline Period & $\begin{array}{l}24 \text { Oct } 1978- \\
1 \text { Aug } 1994\end{array}$ & $\begin{array}{l}1 \text { Aug 1997- } \\
11 \text { Dec } 2010\end{array}$ & $\begin{array}{l}\text { 1 Mar 2002- } \\
8 \text { Apr } 2012\end{array}$ & $\begin{array}{l}18 \text { Dec 1999- } \\
\text { current (Terra) } \\
4 \text { May 2002-current } \\
\text { (Aqua) }\end{array}$ & $\begin{array}{l}26 \text { June } 2010- \\
\text { current }\end{array}$ \\
\hline Orbit type & $\begin{array}{l}\text { LEO (sun- } \\
\text { synchronous } \\
\text { orbit) }\end{array}$ & $\begin{array}{l}\text { LEO (sun- } \\
\text { synchronous } \\
\text { orbit) }\end{array}$ & $\begin{array}{l}\text { LEO (sun- } \\
\text { synchronous } \\
\text { orbit) }\end{array}$ & $\begin{array}{l}\text { LEO (sun- } \\
\text { synchronous orbit) }\end{array}$ & GEO \\
\hline $\begin{array}{l}\text { Local equatorial cross- } \\
\text { ing time (only for } \\
\text { LEO), or longitude } \\
\text { (only for GEO) }\end{array}$ & $\begin{array}{l}\text { 12:00 descend- } \\
\text { ing node }\end{array}$ & $\begin{array}{l}\text { 12:00 descend- } \\
\text { ing node }\end{array}$ & $\begin{array}{l}\text { 10:00 descend- } \\
\text { ing node }\end{array}$ & $\begin{array}{l}\text { 10:30 descending node } \\
\text { (Terra) } \\
\text { 13:30 ascending node } \\
\text { (Aqua) }\end{array}$ & $128.2^{\circ} \mathrm{E}$ \\
\hline Swath (only for LEO) & $1600 \mathrm{~km}$ & $2800 \mathrm{~km}$ & $1150 \mathrm{~km}$ & $2230 \mathrm{~km}$ & \\
\hline Coverage/cycle & $\begin{array}{l}\text { Near-global } \\
\text { coverage every } \\
\text { day }\end{array}$ & $\begin{array}{l}\text { Global } \\
\text { coverage every- } \\
\text { day }\end{array}$ & $\begin{array}{l}\text { Global } \\
\text { coverage in } 3 \\
\text { days }\end{array}$ & $\begin{array}{l}\text { Global coverage nearly } \\
\text { twice/day (long-wave } \\
\text { channels) or once/day } \\
\text { (short-wave channels) }\end{array}$ & $\begin{array}{l}\text { Area of } \\
2500 \mathrm{~km} \times \\
2500 \mathrm{~km} / \mathrm{hourly} \\
\text { in daylight ( } 8 \\
\text { times per day) }\end{array}$ \\
\hline Spatial resolution & $825 \mathrm{~m}$ & $1100 \mathrm{~m}$ & $\begin{array}{l}300 \mathrm{~m}(\mathrm{Eu}- \\
\text { rope) } 1200 \mathrm{~m} \\
\text { (global) }\end{array}$ & $1000 \mathrm{~m}$ & $500 \mathrm{~m}$ \\
\hline $\begin{array}{l}\text { No. of ocean color } \\
\text { channels }\end{array}$ & 6 & 8 & 15 & (total 36 channels) & 8 \\
\hline $\begin{array}{l}\text { Center wavelengths } \\
\text { (and band width) of } \\
\text { ocean color bands (nm) }\end{array}$ & $\begin{array}{l}443(20) \\
520(20) \\
550(20) \\
670(20) \\
750(100) \\
1150(1000)\end{array}$ & $\begin{array}{l}412(20) \\
443(20) \\
490(20) \\
510(20) \\
555(20) \\
670(20) \\
765(40) \\
865(40)\end{array}$ & $\begin{array}{l}412.5(10) \\
442.5(10) \\
490(10) \\
510(10) \\
560(10) \\
620(10) \\
665(10) \\
681.25(7.5) \\
708.75(10) \\
760.625(3.75) \\
778.75(15) \\
865(20) \\
885(10) \\
900(10)\end{array}$ & $\begin{array}{l}412(15) \\
443(10) \\
488(10) \\
531(10) \\
551(10) \\
667(10) \\
678(10) \\
748(10) \\
870(15) \\
\text { (only ocean color } \\
\text { bands are presented.) }\end{array}$ & $\begin{array}{l}412(20) \\
443(20) \\
490(20) \\
555(20) \\
660(20) \\
680(10) \\
745(20) \\
865(40)\end{array}$ \\
\hline
\end{tabular}

\subsection{Cloud masking and quality assurance}

The algorithm is applied to cloud-free and snow-free pixels over land and cloud-free and ice-free pixels over ocean. In order to mask out the cloudy scenes, the following tests are applied:

1. $\rho_{\mathrm{TOA}}(490 \mathrm{~nm})>0.40 \rightarrow$ cloud over land or ocean

2. standard deviation of $3 \times 3$ pixels $\rho_{\mathrm{TOA}}(412 \mathrm{~nm})$ $>0.0025 \rightarrow$ cloud over land
3. standard deviation of $3 \times 3$ pixels $\rho_{\mathrm{TOA}}(550 \mathrm{~nm})$ $>0.0025 \rightarrow$ cloud over ocean

$\rho_{\mathrm{TOA}}(412 \mathrm{~nm}) / \rho_{\mathrm{TOA}}(660 \mathrm{~nm})>0.75 \rightarrow$ dust over ocean (not masked).

The standard deviation test over land is based on the MODIS Deep Blue (DB) algorithm (Hsu et al., 2004), and other tests are based on the MODIS Dark Target (DT) (Remer et al., 2005). Note that ocean pixels with glint angle less than $40^{\circ}$ are also masked out. After the cloud masking, $12 \times 12 \mathrm{GOCI}$ $500 \mathrm{~m}$ resolution pixels (resulting in $6 \mathrm{~km} \times 6 \mathrm{~km}$ resolution) 


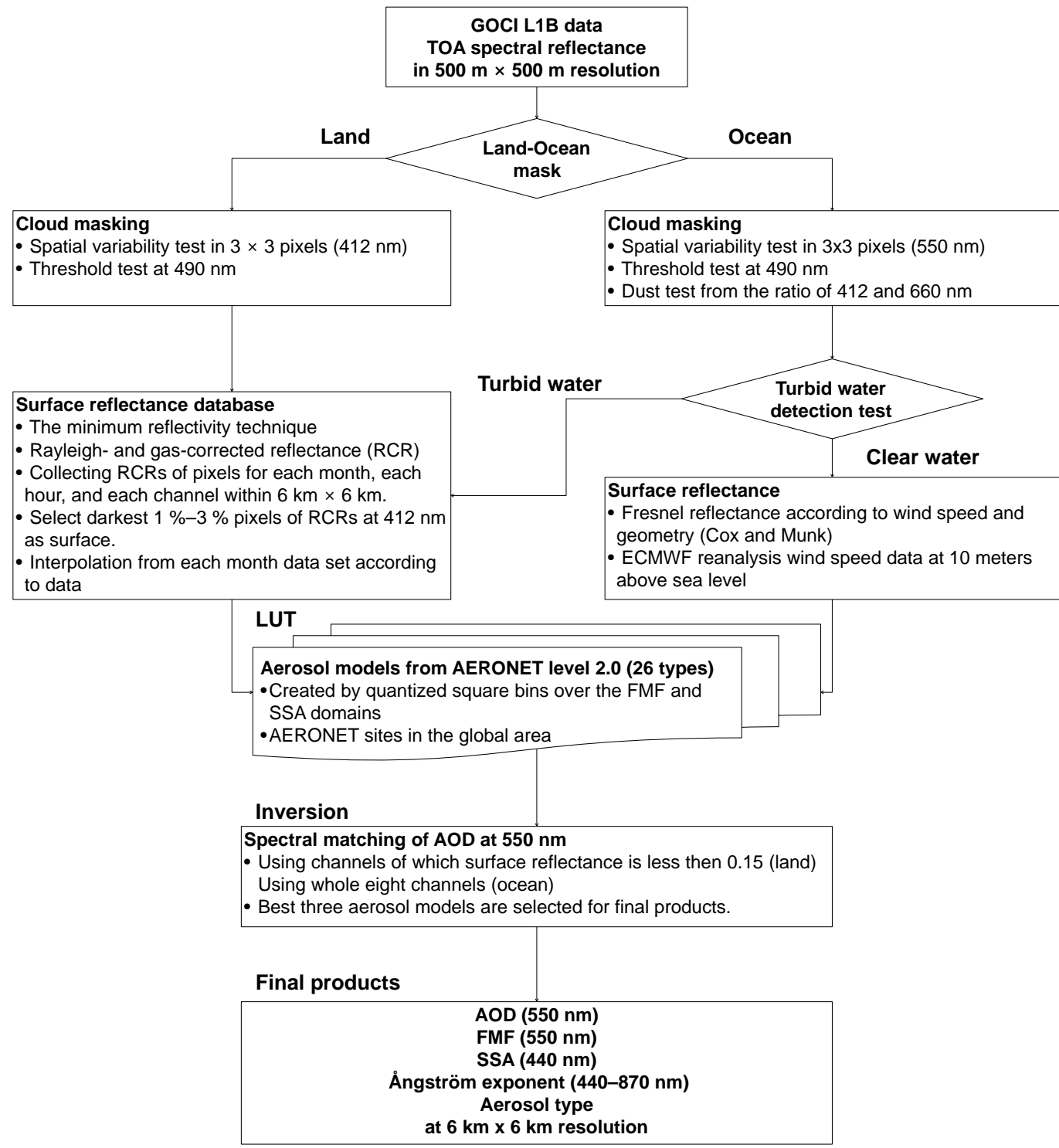

Figure 1. Flowchart for GOCI YAER algorithm.

are aggregated to be fed into the retrieval process. In this step, the darkest $20 \%$ and the brightest $40 \%$ of pixels in reference to $\rho_{\mathrm{TOA}}(490 \mathrm{~nm})$ are discarded to remove remaining cloud, cloud shadow, and surface contamination (Remer et al., 2005; Levy et al., 2007). The number of L1B pixels remaining and the retrieved AOD at $550 \mathrm{~nm}$ determine the quality assurance (QA) flag for each retrieval pixel, as listed in Table 2. Thresholds of QA determination are based on the MODIS DT algorithm (Levy et al., 2013). The GOCI YAER algorithm allows a retrieved AOD range from -0.1 to 5.0, and QA can be only greater than 1 only when the value is in the range between -0.05 and 3.6. The algorithm allows randomly retrieved, small negative AOD caused by uncertainty in surface reflectance because it is within the expected retrieval error with reference to the MODIS DT algorithm, and also has statistical significance in low AOD range (Levy et al., 2007, 2013).

\subsection{Surface reflectance over land and ocean}

The lack of a $2.1 \mu \mathrm{m}$ channel in GOCI limits the capability of estimating surface reflectance in the visible from the $2.1 \mu \mathrm{m}$ TOA reflectance as in the MODIS DT algorithm (Levy et al., 2007; Kaufman et al., 1997b). Instead, the GOCI YAER algorithm uses the minimum reflectivity technique to determine the surface reflectance $\left(\rho_{\mathrm{SFC}}\right)$ over land and turbid water (Herman and Celarier, 1997; Hsu et al., 2004; Koelemeijer et al., 2003). First, each scene's TOA reflectance is corrected for Rayleigh scattering to derive the Rayleighcorrected reflectance (RCR) (Hsu et al., 2013). It is assumed 
Table 2. Conditions for determining pixel QA values from 0 to 3.

\begin{tabular}{llr}
\hline QA & $\begin{array}{l}\text { Number of pixels }(N) \text { selected } \\
\text { from possible } 12 \times 12 \text { pixels }\end{array}$ & Range of retrieved AOD at $550 \mathrm{~nm}$ \\
\hline 0 & $6 \leq N \leq 14$ & $-0.10 \leq \mathrm{AOD}<0.05$, or $3.6<\mathrm{AOD} \leq 5.0$ \\
1 & $15 \leq N \leq 21$ & $-0.05 \leq \mathrm{AOD} \leq 3.6$ \\
2 & $22 \leq N \leq 35$ & $-0.05 \leq \mathrm{AOD} \leq 3.6$ \\
3 & $36 \leq N \leq 58$ (maximum) & $-0.05 \leq \mathrm{AOD} \leq 3.6$ \\
\hline
\end{tabular}

that in a 30-day period, changes in surface reflectance are insignificant and there is at least 1 clear day (Lee et al., 2010b). To increase the number of samples to find clear pixels, it is also assumed that the surface reflectance is homogeneous over $12 \times 12$ pixels; therefore L1B resolution data are used for determining the minimum reflectance. Thus, the spatial resolution of surface reflectance is the same as the aerosol retrieval resolution of $6 \mathrm{~km} \times 6 \mathrm{~km}$. To allow for changes of surface reflectance with sun-satellite geometry, RCRs at a given hour during the day are composited for each month. The maximum number of samples available to determine surface reflectance at a pixel is 144 pixels $\times 30$ days, a total of 4320 samples. Samples are sorted in ascending order according to RCR at $412 \mathrm{~nm}$ and selected from the darkest 1 to $3 \%$. At $412 \mathrm{~nm}$, the variability of surface reflectance is lower and atmospheric signals such as Rayleigh scattering or aerosol reflectance are higher than at longer wavelengths. Thus, the RCR at $412 \mathrm{~nm}$ is used to find clear pixels during the 30-day window. According to Hsu et al. (2004), a surface reflectance database can be obtained by finding the minimum value of the $412 \mathrm{~nm}$ RCR within a given month, which corresponds to about $3 \%$ for the window. In this process, cloud shadows which could lead to false reflectance should not be selected to evaluate surface reflectance. For example, Lee et al. (2010b) selected the second minimum value, and Fukuda et al. (2013) used the modified minimum reflectance method using first and second minimum values to avoid cloud shadow effects for determining surface reflectance. In the GOCI YAER algorithm, the maximum number of L1B pixel samples for one surface reflectance pixel at a given time is 144 pixels $\times 30$ days, a total of 4320 samples. Therefore, using only the first or second minimum threshold is not appropriate for the GOCI YAER algorithm. Instead, darkest $0-1 \%$ pixels are assumed to be cloud shadow and are thus excluded, empirically. Therefore, thresholds for the lower and upper bound are set as $1 \%$ and $3 \%$, respectively. The RCRs of selected pixels are averaged for each channel, giving a surface reflectance corresponding to the middle of each month (day 15). Finally, linear interpolation according to retrieval date is applied.

Figure 2 shows examples of surface reflectance at 443 and $660 \mathrm{~nm}$; the difference in the surface reflectance between ocean and land is smaller at $443 \mathrm{~nm}$ than $660 \mathrm{~nm}$. The high $660 \mathrm{~nm}$ surface reflectance near the coast of China in the Bo- hai Sea and in the northern East China Sea shows turbid water with values comparable to the land surface reflectance over northern China and higher than southern China; this clearly shows a semi-permanent presence of turbid water pixels during the 30 days. From March to May, surface reflectances decrease over land because of melting snow and increasing vegetation. According to von Hoyningen-Huene et al. (2003), who described the aerosol retrieval algorithm using ocean color sensors, pixels with a surface reflectance of less than 0.15 correspond to areas fully or partly covered with vegetation. Also, Zhang et al. (2011) described that the operational GOES AOD retrieval algorithm use a simple threshold of 0.15 surface reflectance to remove bright surface reflectance pixels. Final selected channels for retrieving aerosol over land are those of which surface reflectances are less than 0.15 .

On the other hand, it is assumed that ocean surface reflectance varies with geometry and wind speed (Cox and Munk, 1954); the wind speed at $10 \mathrm{~m}$ above sea level is used in a radiative transfer model to calculate the look-up table (LUT). The nodal points of wind speed in the LUT calculation are $1,3,5,7,9$, and $20 \mathrm{~m} \mathrm{~s}^{-1}$, which are the default nodal points of libRadtran package. Using the European Centre for Medium-Range Weather Forecasts' (ECMWF) wind speed reanalysis data with $0.25^{\circ} \times 0.25^{\circ}$ spatial resolution every $6 \mathrm{~h}$, the LUT is interpolated to each pixel's wind speed to retrieve the AOD over the ocean.

\subsection{Turbid water detection}

Retrieving aerosol properties over turbid water is challenging due to the variability of the turbid water and high surface reflectance. Half of the ocean in the GOCI observation area is the Yellow Sea with very high year-round turbidity. If the ocean surface is assumed over turbid water, the surface reflectance can be underestimated, and thus AOD can be overestimated. The previous GOCI YAER algorithm (Lee et al., 2010b) used the surface reflectance ratio for turbid water detection, which is the ratio of surface reflectance at 640 and $860 \mathrm{~nm}$. If turbid water pixels are detected, the surface reflectance from the second minimum RCR during the previous 30-day period is used for AOD retrieval. Persistent areas of turbid water during the previous 30 days can be detected in this way, but it is hard to detect rapid temporal variations 

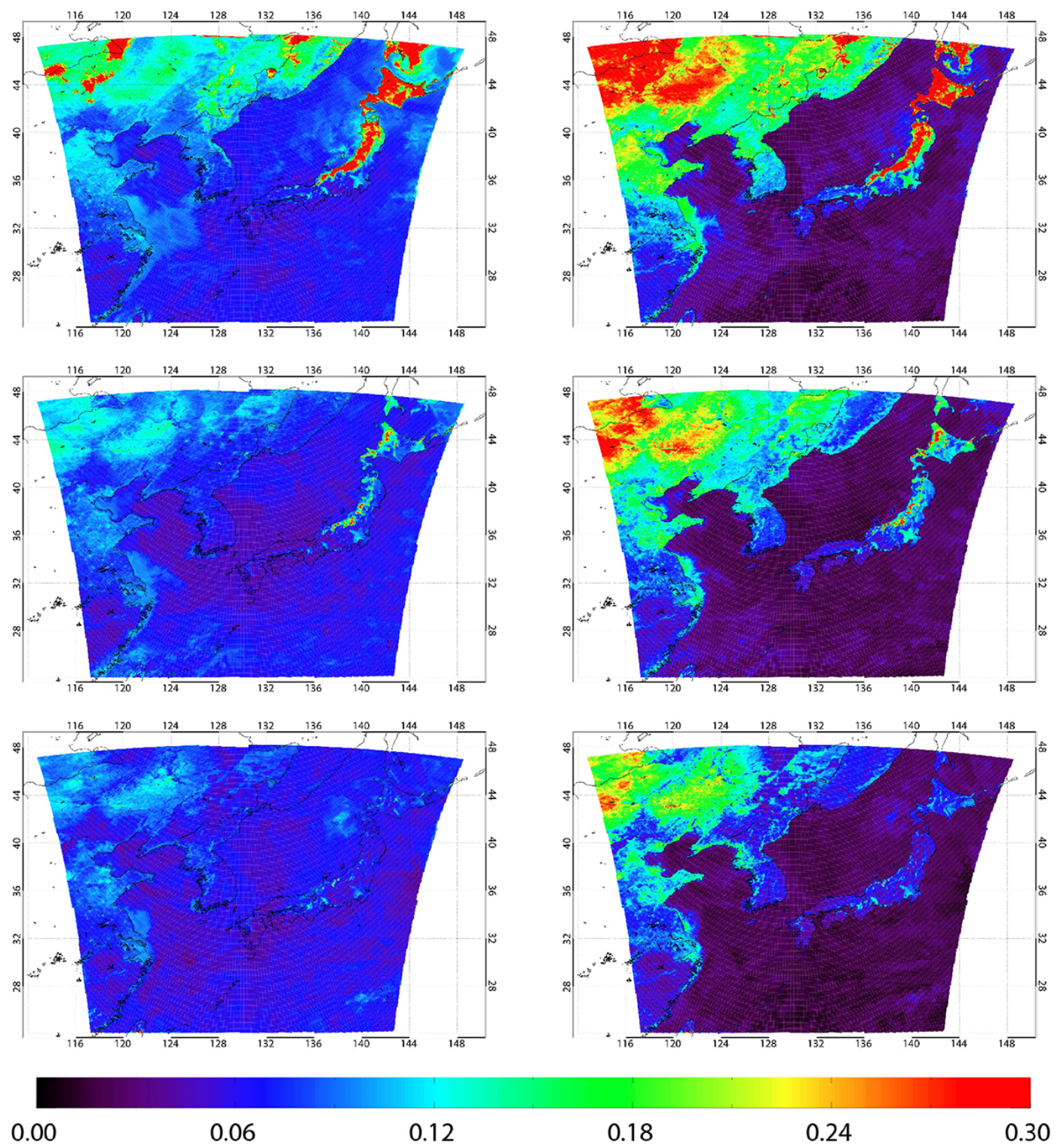

Figure 2. Surface reflectance on 15th of the month, 13:30 local standard time (LST) at $443 \mathrm{~nm}$ (left column) and 660 nm (right column): March (upper row), April (middle row), and May (lower row).

of turbidity. In this study, real-time turbid water detection is applied.

According to $\mathrm{Li}$ et al. (2003), $\rho_{\mathrm{TOA}}$ at 550, 660, and $865 \mathrm{~nm}$ showed higher values over turbid water than over clear water. They used the difference between $\rho_{\mathrm{TOA}}$ at $550 \mathrm{~nm}$ and the value interpolated to $550 \mathrm{~nm}$ from $\rho_{\text {TOA }}$ at $470,1240,1640$, and $2130 \mathrm{~nm}$ using a linear fit on a log-log scale. In this study, because GOCI does not have infrared (IR) channels, $\Delta \rho_{660}$ is defined as the difference in reflectance at $660 \mathrm{~nm}$ between the observed $\rho_{\mathrm{TOA}}$ at $660 \mathrm{~nm}$ and linearly interpolated between $\rho_{\mathrm{TOA}}$ at 412 and $865 \mathrm{~nm}$ to $660 \mathrm{~nm}$. Increased $\rho_{\mathrm{TOA}}$ due to turbid water is stronger at $660 \mathrm{~nm}$ than at
412 and $865 \mathrm{~nm}$; therefore $\Delta \rho_{660}$ shows a higher value over turbid water than over clear water.

To determine the threshold of $\Delta \rho_{660}$ for distinguishing turbid and clear water over the ocean, hourly data for the first and fifteenth day of each month for 3 years from March 2011 to February 2014 are analyzed. The analysis is implemented over two distinct areas: the Yellow Sea $\left(115-126^{\circ} \mathrm{E}, 30\right.$ $\left.40^{\circ} \mathrm{N}\right)$ and an area of clear water $\left(130-140^{\circ} \mathrm{E}, 25-30^{\circ} \mathrm{N}\right)$, as in Lee et al. (2010b). A strict threshold for defining pixels as clear water is necessary to prevent misdetection of less turbid water as aerosol. Figure 3 shows the cumulative normal distribution of $\Delta \rho_{660}$, where ratios below -0.05 are $99.0 \%$ and $67.4 \%$ for clear water and Yellow Sea pixels, respec- 

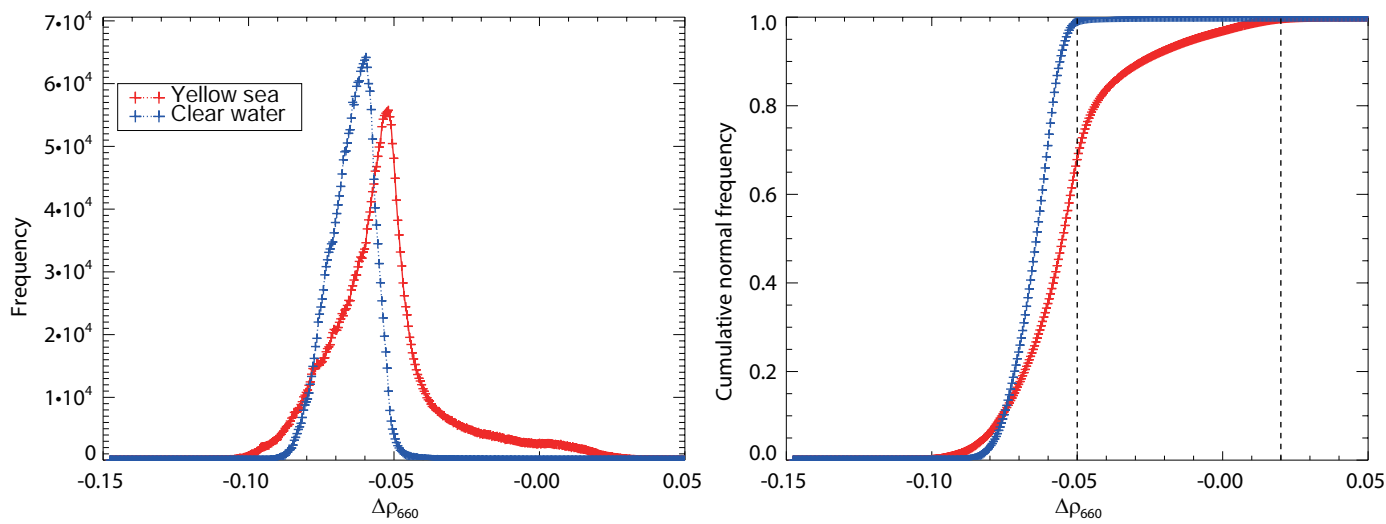

Figure 3. Frequency and cumulative normal frequency of $\Delta \rho_{660}$ over the Yellow Sea and over clear water.

tively. Finally, pixels with $\Delta \rho_{660}$ below -0.05 are not considered as turbid water; consequently, the ocean algorithm is applied. On the contrary, pixels where $\Delta \rho_{660}$ is above -0.05 are considered as turbid water; therefore the land algorithm is applied. Note that the surface reflectance of turbid water pixels is adjusted to the minimum turbidity during the 30 days; therefore surface reflectance can be underestimated when severely turbid water occurs within the 30 days. Values of the ratio below 0.02 comprise $99.6 \%$ of the Yellow Sea pixels. Therefore, pixels where $\Delta \rho_{660}$ is above 0.02 are considered as severely turbid water, and excluded from the retrieval procedure.

To confirm whether $\Delta \rho_{660}$ effectively detects turbid water, two turbid water cases are selected in Fig. 4. One is a clean atmosphere case (26 April 2012), and another case involves dust over the northern part of the Yellow Sea (27 April 2012). To compare the sensitivity between pixels over turbid water and those with absorbing aerosol, the Deep Blue Aerosol Index (DAI) is calculated using GOCI TOA reflectance at 412 and $443 \mathrm{~nm}$ (Hsu et al., 2004, 2006; Ciren and Kondragunta, 2014). Note that DAI and $\Delta \rho_{660}$ are plotted over cloud-free pixels, and only positive DAI pixels are presented to check the existence of absorbing aerosol such as dust in Fig. 4e and $\mathrm{f}$, because absorbing aerosol such as dust or smoke shows a DAI greater than 4 over ocean (Ciren and Kondragunta, 2014). The true color image for the clean case shows severe turbidity in the ocean along the coast of eastern China and the western Korean Peninsula. The next day, there is heavy Asian dust over northern Yellow Sea, and turbid water is in the same position as the day before. $\Delta \rho_{660}$ shows a higher signal over turbid water $(\sim 0.02)$ than Asian dust $(\sim-0.01)$, while DAI shows a higher signal over Asian dust $(\sim 4.8)$ than turbid water $(\sim 1.6)$. Although heavy aerosol plumes can have $\Delta \rho_{660}$ above -0.05 over clear water, this does not cause a significant issue because the land algorithm is applied instead, not affecting spatial coverage.

An additional role of $\Delta \rho_{660}$ is to detect the remaining cloud-contaminated pixels after cloud masking. There are in- homogeneous cloud pixels over the right half of the scene in Fig. 5. Most cloud pixels are effectively screened by the cloud masking steps, but thin cloud pixels remain and show high $\Delta \rho_{660}$ above 0.05 (red color). This is a similar to the "visible reflectance" anomaly of the VIIRS aerosol algorithm (Jackson et al., 2013). Because pixels with $\Delta \rho_{660}$ above 0.02 are considered as severe turbid water and screened, the remaining cloud pixels are also masked using this test. The average ratio of pixels of $\Delta \rho_{660}$ above 0.02 after cloud masking over total available ocean pixels is about $2 \%$ during the campaign.

\subsection{Aerosol models}

There are various factors to determine aerosol characteristics and aerosols' change such as temporal and spatial variations of the direct emission, secondary production, and meteorological transport (Yoon et al., 2011, 2012, 2014). In addition, it is important to reflect those properties well from the perspective of optical properties for aerosol retrieval. Assumed aerosol models play an important role in the retrieval accuracy. To reflect global climatological properties, AERONET inversion data (Dubovik and King, 2000) are used for creating aerosol models to be used in the retrieval process. A classification method for AERONET inversion data using finemode fraction (FMF) at $550 \mathrm{~nm}$ and single-scattering albedo (SSA) at $440 \mathrm{~nm}$ is adopted (J. Kim et al., 2007; Lee et al., 2010a, 2012), but there are some differences for the GOCI YAER algorithm.

Composited AERONET data are only used for the period up to February 2011, which is before GOCI's first observation, to separate AERONET data usages for aerosol model construction and validation of satellite products. Global sites are selected where the number of individual AERONET retrieval data is greater than 10 times, giving a total of 747 sites. Observation periods of individual AERONET sites are quite different, from few individual observations to several years. Level 2.0 data are quality assured; consequently, each individual observation is meaningful, even if the whole ob- 
(a)

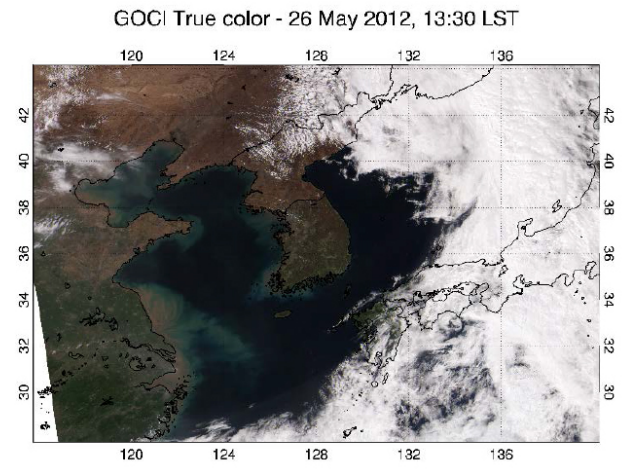

(c)

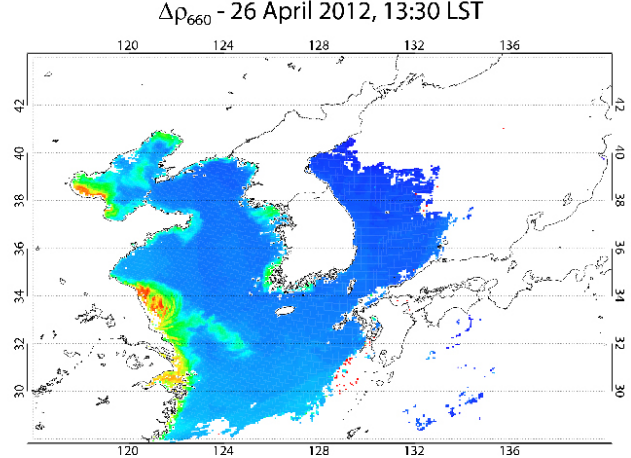

(b)

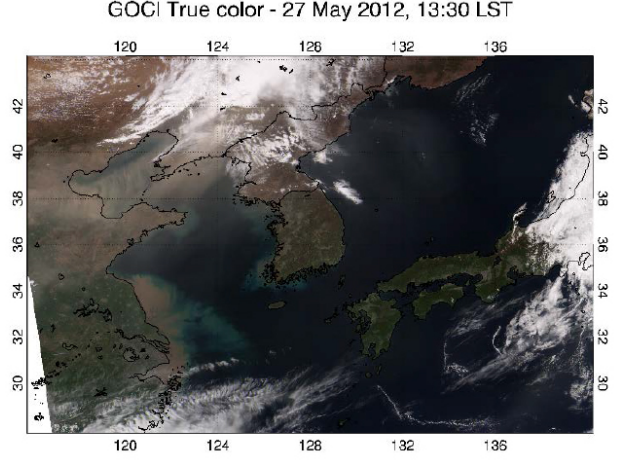

(d)

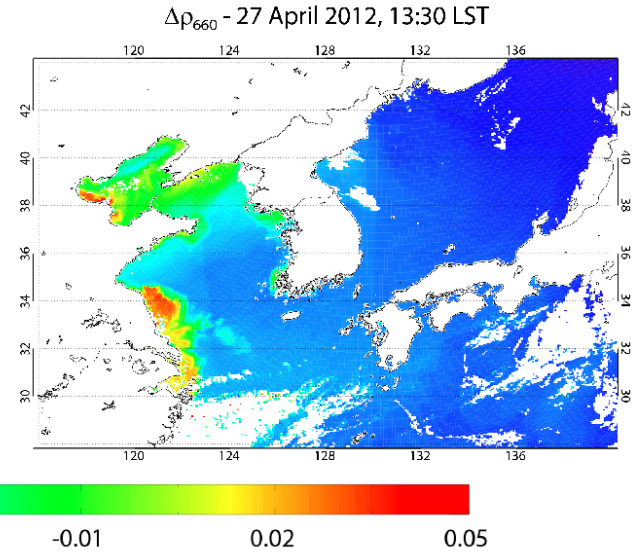

(e)

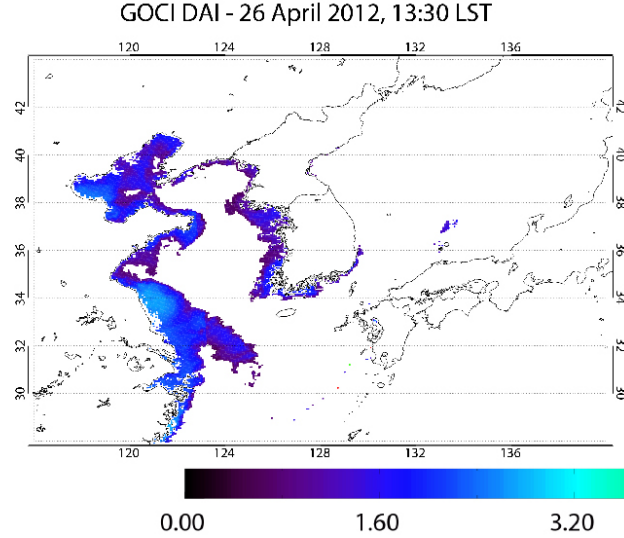

(f)

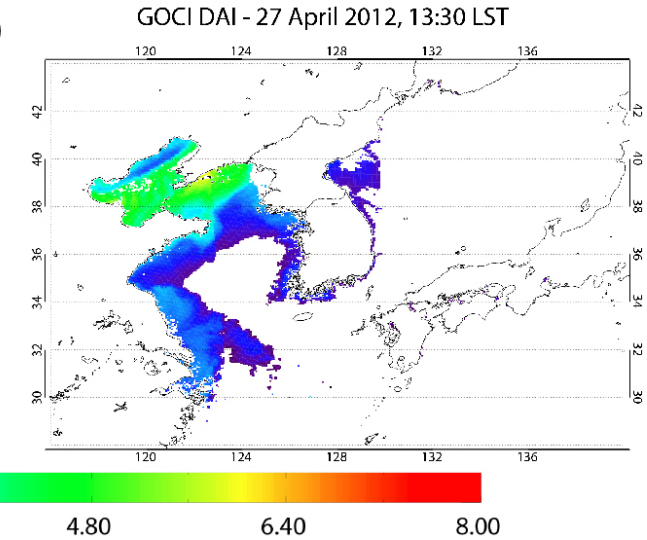

Figure 4. $\Delta \rho_{660}$ and DAI images at 13:30 LST on (a), (b) 26 April 2012 (no dust case) and (c), (d) the following day (dust case), respectively.

servation period is short. Therefore, we tried to use available AERONET individual data, and a small threshold of 10 times is applied. From those sites, the number of data that have all the AOPs in all channels is 66712 . They are classified into 26 aerosol models according to FMF at $550 \mathrm{~nm}$ and SSA at $440 \mathrm{~nm}$ (Table 3). Note that AOPs change as AOD varies because of the hygroscopic growth effect or aggregation (Reid et al., 1998; Eck et al., 2003). Therefore, each aerosol model is separated again into low, moderate, and high AOD groups corresponding to the AOD ranges of $0.0-0.5,0.5-0.8$, and 0.8-3.6 respectively. Finally, the AOPs of each aerosol model are averaged and used as input for the LUT calculation.
The AERONET inversion algorithm considers aerosol nonsphericity using a mixture of polydisperse, randomly oriented homogeneous spheroids (Mishchenko et al., 1997; Dubovik et al., 2006). Phase functions of the inversion data including the effect of nonspherical particles are directly used for the radiative transfer calculations.

\subsection{LUT calculation and inversion procedure}

Table 4 shows the node points for calculating TOA reflectances using a discrete ordinate radiative transfer (DISORT) code of the libRadtran software package (http:// 
(a)

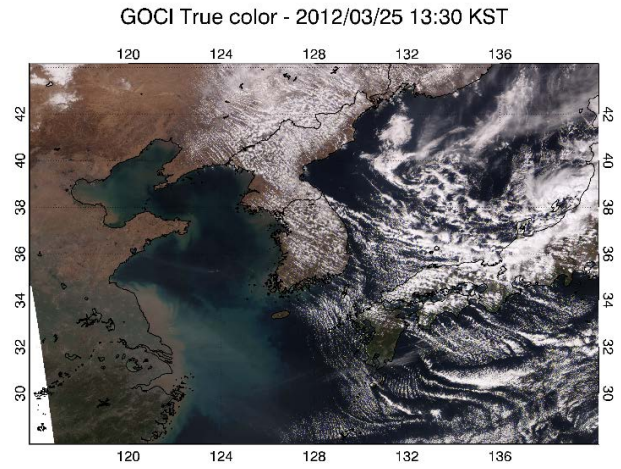

(b)

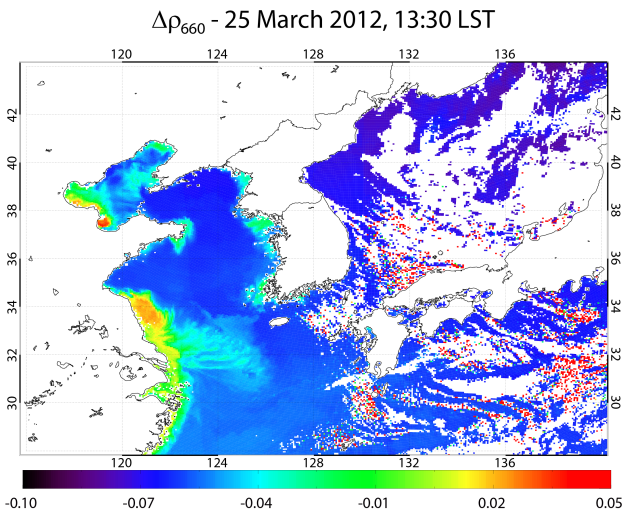

Figure 5. 25 March 2012, 13:30 LST (a) true color image and (b) $\Delta \rho_{660}$.

Table 3. The number of AERONET inversion data, and considering AE between 440 and $870 \mathrm{~nm}$, FMF at $550 \mathrm{~nm}$, and SSA at $440 \mathrm{~nm}$ for the 26 aerosol models. The minimum and maximum values are shown because of AOD dependence. H, M, and $\mathrm{N}$ denote highly absorbing, moderately absorbing, and non-absorbing models, respectively.

\begin{tabular}{|c|c|c|c|c|c|c|c|c|c|}
\hline & & & & & $\mathrm{FMF}(550 \mathrm{~nm})$ & & & & \\
\hline \multirow{6}{*}{$0.85-0.90$} & $0.1-0.2$ & $0.2-0.3$ & $0.3-0.4$ & $0.4-0.5$ & $0.5-0.6$ & $0.6-0.7$ & $0.7-0.8$ & $0.8-0.9$ & $0.9-1.0$ \\
\hline & H1 & $\mathrm{H} 2$ & $\mathrm{H} 3$ & $\mathrm{H} 4$ & H5 & H6 & H7 & $\mathrm{H} 8$ & H9 \\
\hline & 3298 & 4309 & 1960 & 1360 & 1151 & 1256 & 2145 & 3420 & 1933 \\
\hline & $0.094-0.184$ & $0.336-0.366$ & $0.563-0.632$ & $0.674-0.855$ & $0.832-1.065$ & $1.140-1.239$ & $1.230-1.430$ & $1.305-1.569$ & $1.570-1.617$ \\
\hline & $0.156-0.173$ & $0.243-0.247$ & $0.339-0.345$ & $0.447-0.448$ & $0.541-0.553$ & $0.647-0.652$ & $0.756-0.758$ & $0.852-0.857$ & $0.928-0.934$ \\
\hline & $0.883-0.886$ & $0.880-0.881$ & $0.871-0.881$ & $0.874-0.877$ & $0.876-0.879$ & $0.877-0.882$ & $0.876-0.879$ & $0.880-0.881$ & $0.880-0.884$ \\
\hline \multirow{5}{*}{$0.90-0.95$} & M1 & M2 & M3 & M4 & M5 & M6 & M7 & M8 & M9 \\
\hline & 5699 & 6111 & 2396 & 1606 & 1185 & 1431 & 2344 & 5520 & 6641 \\
\hline & $0.132-0.182$ & $0.278-0.366$ & $0.421-0.638$ & $0.408-0.868$ & $0.765-1.070$ & $1.082-1.270$ & $1.203-1.452$ & $1.276-1.623$ & $1.563-1.648$ \\
\hline & $0.165-0.174$ & $0.227-0.246$ & $0.340-0.350$ & $0.445-0.447$ & $0.548-0.552$ & $0.649-0.652$ & $0.754-0.755$ & $0.856-0.863$ & $0.934-0.946$ \\
\hline & $0.918-0.920$ & $0.920-0.921$ & $0.921-0.922$ & $0.922-0.922$ & $0.917-0.923$ & $0.915-0.923$ & $0.919-0.926$ & $0.920-0.927$ & $0.927-0.930$ \\
\hline \multirow{4}{*}{$0.95-1.00$} & & $\mathrm{~N} 1$ & $\mathrm{~N} 2$ & N3 & $\mathrm{N} 4$ & N5 & N6 & N7 & N8 \\
\hline & & 558 & 366 & 289 & 279 & 382 & 845 & 2643 & 7585 \\
\hline & & $0.276-0.380$ & $0.464-0.645$ & $0.452-0.877$ & $0.711-1.065$ & $1.032-1.275$ & $1.191-1.464$ & $1.258-1.652$ & $1.426-1.744$ \\
\hline & & $0.230-0.248$ & $0.344-0.350$ & $0.441-0.448$ & $0.546-0.555$ & $0.654-0.658$ & $0.756-0.759$ & $0.860-0.869$ & $0.941-0.956$ \\
\hline
\end{tabular}

libradtran.org) (Mayer and Kylling, 2005). The input options of this radiative transfer model (RTM) to calculate $\rho_{\mathrm{TOA}}$ for different aerosol conditions include the spectral phase function and SSA; therefore the values of each model from AERONET inversion data can be used directly. Note that the input spectral AODs for LUT calculation are normalized to $550 \mathrm{~nm}$ using the climatology of each model's Ångström exponent (AE) between 440 and $870 \mathrm{~nm}$.

The inversion method is adopted from that of Lee et al. (2012). That algorithm retrieves AOD at $550 \mathrm{~nm}$ using every MODIS wavelength $(470,555,650,860,1240,1630$, and $2010 \mathrm{~nm}$ ) and aerosol model, and then the aerosol model is selected that minimized the standard deviation of the seven different AODs retrieved from each wavelength. The final AOD is chosen from each wavelength. By doing so, each wavelength can contribute equally to selecting the aerosol model. In the GOCI YAER algorithm, the reference channel is the same as $550 \mathrm{~nm}$ and retrieval wavelengths are changed to the GOCI wavelengths.
The GOCI YAER algorithm retrieves AODs at $550 \mathrm{~nm}$ using whole GOCI wavelengths' reflectance $(412,443,490$, $555,660,680,745$, and $865 \mathrm{~nm}$ ) and aerosol model over ocean. Final selected wavelengths for retrieving aerosol properties over land are those of which surface reflectances are less than 0.15 . If the number of selected wavelengths is greater than or equal to 2, AODs at $550 \mathrm{~nm}$ are retrieved from that wavelength and aerosol model. The inversion procedure to retrieve AOD is implemented using interpolation from precalculated TOA reflectance at LUT dimensions to observed TOA reflectance according to geometries (solar zenith angle, satellite zenith angle, and relative azimuth angle), assumed aerosol model, wavelength, surface reflectance, and terrain height. Then, three aerosol models are selected that minimized the standard deviation $(\sigma)$ of the different AODs retrieved from each wavelength, defined as the square root of the average of the squared deviations of the AODs from their average AOD. Final products of AOD, FMF, SSA, and AE are the $\sigma$-weighted average value from three selected models 
Table 4. LUT dimensions.

\begin{tabular}{lrl}
\hline Variable & $\begin{array}{r}\text { Number } \\
\text { of entries }\end{array}$ & Entries \\
\hline Wavelength & 8 & $\begin{array}{l}412,443,490,555,660,680,765,870 \mathrm{~nm} \\
\text { (considering spectral response function) }\end{array}$ \\
$\begin{array}{l}\text { Solar zenith angle } \\
\text { Satellite zenith angle }\end{array}$ & 8 & $0,10, \ldots, 70^{\circ}\left(10^{\circ}\right.$ interval) \\
$\begin{array}{l}\text { Relative azimuth angle } \\
\text { AOD }\end{array}$ & 8 & $0,10, \ldots, 70^{\circ}\left(10^{\circ}\right.$ interval) \\
$\begin{array}{l}\text { Aerosol model } \\
\text { Surface reflectance } \\
\text { (only for land LUT) }\end{array}$ & 9 & $0,10, \ldots, 180^{\circ}\left(10^{\circ}\right.$ interval) \\
Terrain height & 26 & $\begin{array}{l}\text { In Table } 2 \\
\text { (only for land LUT) }\end{array}$ \\
$\begin{array}{l}\text { Wind speed } \\
\text { (only for ocean LUT) }\end{array}$ & 4 & $0.0,0.1,0.2$ \\
\hline
\end{tabular}

Table 5. Output aerosol types for GOCI YAER according to FMF and SSA.

\begin{tabular}{|c|c|c|c|}
\hline No. & Aerosol type & FMF $(550 \mathrm{~nm})$ & SSA $(440 \mathrm{~nm})$ \\
\hline 1 & Dust & $0.0 \leq \mathrm{FMF}<0.4$ & $\mathrm{SSA} \leq 0.95$ \\
\hline 2 & Non-absorbing coarse type & $0.0 \leq \mathrm{FMF}<0.4$ & $0.95<\mathrm{SSA}<1.00$ \\
\hline 3 & Mixture & $0.4 \leq \mathrm{FMF}<0.6$ & \\
\hline 4 & Highly absorbing fine type & $0.6 \leq \mathrm{FMF}<1.0$ & $\mathrm{SSA}<0.90$ \\
\hline 5 & Moderately absorbing fine type & $0.6 \leq \mathrm{FMF}<1.0$ & $0.90 \leq \mathrm{SSA}<0.95$ \\
\hline 6 & Non-absorbing fine type & $0.6 \leq \mathrm{FMF}<1.0$ & $\mathrm{SSA} \geq 1.00$ \\
\hline
\end{tabular}

as shown in the following equations:

Final AOD at $550 \mathrm{~nm}=\sum_{i=1}^{3} C_{\text {Model } i} \times$ Averaged AOD $_{\text {Model } i}$

$C_{\text {Model } i}=\frac{\frac{1}{\sigma_{\text {Model } i}}}{\frac{1}{\sigma_{\text {Model } 1}}+\frac{1}{\sigma_{\text {Model } 2}}+\frac{1}{\sigma_{\text {Model } 3}}}$.

Final AE between 440 and $870 \mathrm{~nm}, \mathrm{FMF}$ at $550 \mathrm{~nm}$, and SSA at $440 \mathrm{~nm}$ are determined in the same way except that averaged AOD is replaced with assumed AOPs as in Table 3. The GOCI YAER algorithm classifies a total of six aerosol types using the retrieved final FMF and SSA (Table 5).

\section{Case studies of GOCI YAER products during the DRAGON-NE Asia 2012 campaign}

Aerosol types of East Asia are very diverse and complicated. Dust occurs sporadically in the Gobi Desert and Taklamakan Desert of the continent of Asia and anthropogenic aerosols occur in urban/industrial sites. Highly absorbing and finedominated, non-absorbing and fine-dominated, marine, and dust aerosols are observed similarly over East Asia (Lee et al., 2014). East China Sea and Yellow Sea are located between the continent of Asia and the Korean Peninsula; therefore the long-range transport of aerosols could be detected clearly. During the DRAGON-NE Asia 2012 campaign, there were high aerosol loading cases. Two representative cases are presented here, the heavy pollution haze case on 6 May, and the dust case on 27 April. On 6 May 2012, a white haze plume was detected over northeastern China and the Yellow Sea from the true color image as shown in Fig. 6a. GOCI YAER AOD, FMF, AE, SSA, and aerosol type are plotted in Fig. 6b-f. Note that all pixels regardless of QA values are included in the AOD plot, while only pixels with positive AOD are shown for the other products. High AOD ranging from 1.2 to 2.0 is found at the center of the haze plume, with retrieved FMF and AE of about 0.8 and 1.2, respectively. This means that the haze aerosol is a fine-mode dominant aerosol. The retrieved SSAs at those pixels are in the range $0.955-0.975$, corresponding to non-absorbing aerosol. The detected aerosol type of the haze is therefore classified as non-absorbing fine aerosol, shown in blue in Fig. $6 \mathrm{f}$.

The distribution of FMF, AE, and SSA over land is more inhomogeneous than over ocean, particularly, for pixels with low AOD, which is likely due to the higher surface reflectance, higher spatial variability, and higher uncertainty of land surface reflectance than that of ocean. Nevertheless, it is encouraging that there is less discrepancy between ocean and land, with products showing a continuous distribution across the coastline for both high $(\sim 1.0)$ and low AOD $(\sim 0.3)$ pixels.

Another case is a severe dust case on 27 April 2012 as shown in Fig. 7. Heavy yellow dust plumes are evident in the 
(a)

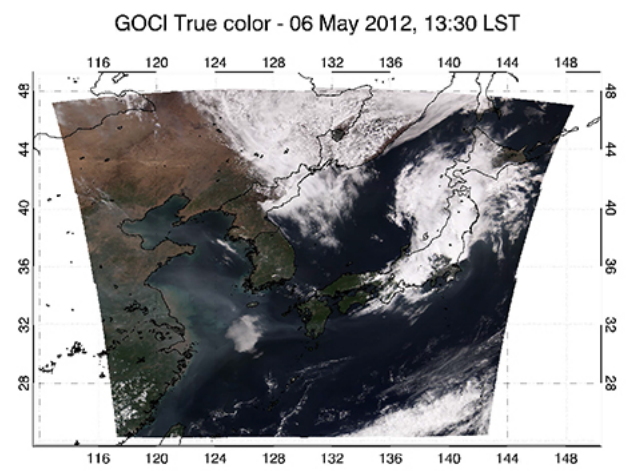

(c)

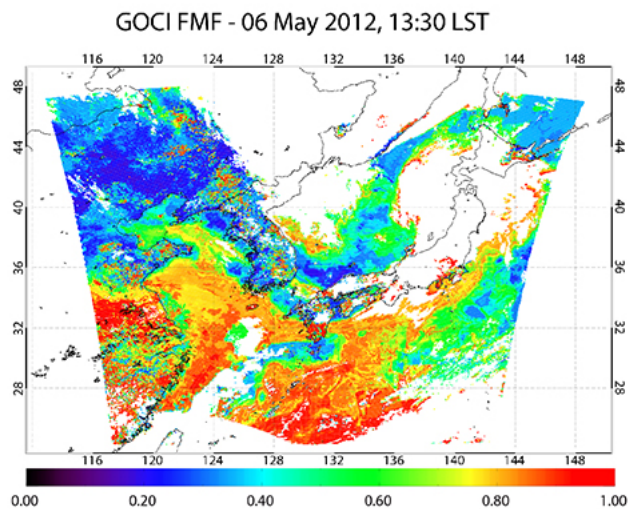

(e)

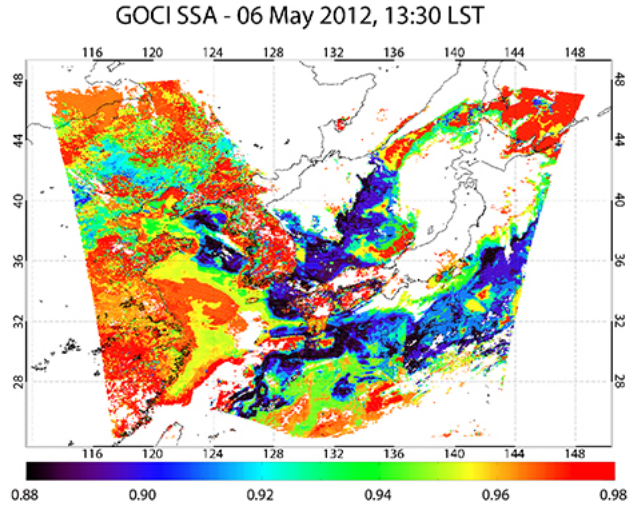

(b)

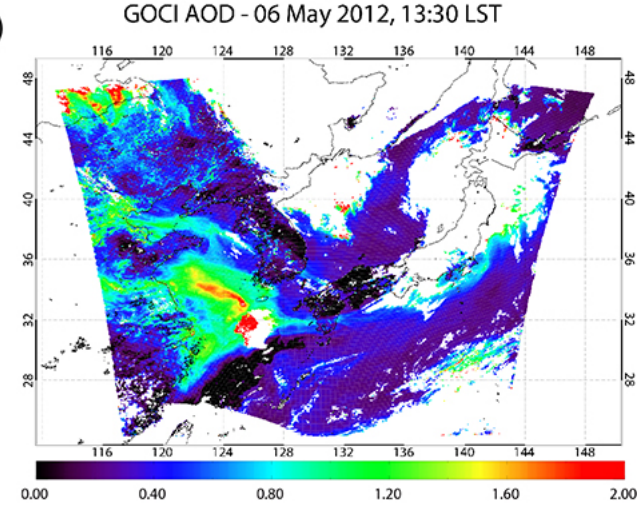

(d)

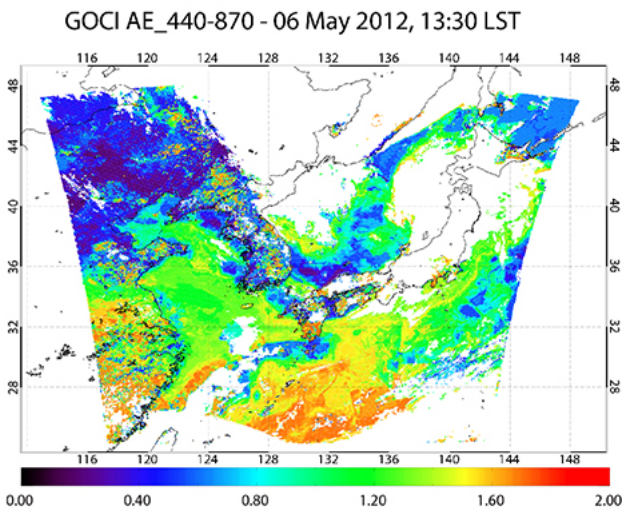

(f)

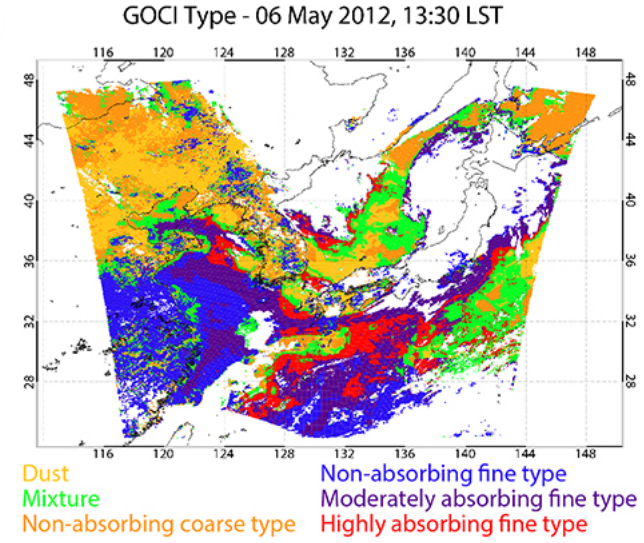

Figure 6. Images of (a) GOCI true color, (b) AOD at $550 \mathrm{~nm}$, (c) FMF at $550 \mathrm{~nm}$, (d) AE between 440 and $870 \mathrm{~nm}$, (e) SSA at $440 \mathrm{~nm}$, and (f) type for 6 May 2012, 13:30 LST. Aerosol types are colored yellow (dust), green (mixture), orange (non-absorbing coarse type), blue (non-absorbing fine type), purple (moderately absorbing fine type), and red (highly absorbing fine type).

GOCI true color image. These developed in the Gobi Desert the previous day and were transported to the northern part of the Korean Peninsula across the Yellow Sea. The dust plume has a horizontal scale about $1000 \mathrm{~km}$ from inland China to the Yellow Sea, with AOD at its center above 2.0 (red color), and about 1.2 at the edge of the plume. The dust plume over the northern part of the Korean Peninsula is mixed with cloud, but the plume in the southern part shows low AOD of about 0.3 , with FMF and AE of 0.3 and 0.5, respectively, corresponding to coarse-mode-dominated aerosol. SSA ranges from 0.90 to 0.92 , corresponding to moderately absorbing aerosol. From the FMF and SSA, the aerosol plume is classified as dust, shown in yellow in Fig. 7f.

\section{Evaluation of GOCI YAER products during the DRAGON-NE Asia 2012 campaign}

Generally, in spring, various aerosol events such as yellow dust or anthropogenic aerosol occur frequently and inten- 
(a)

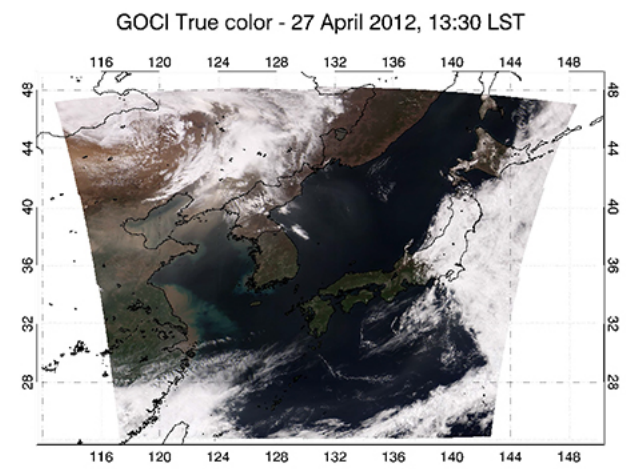

(c)

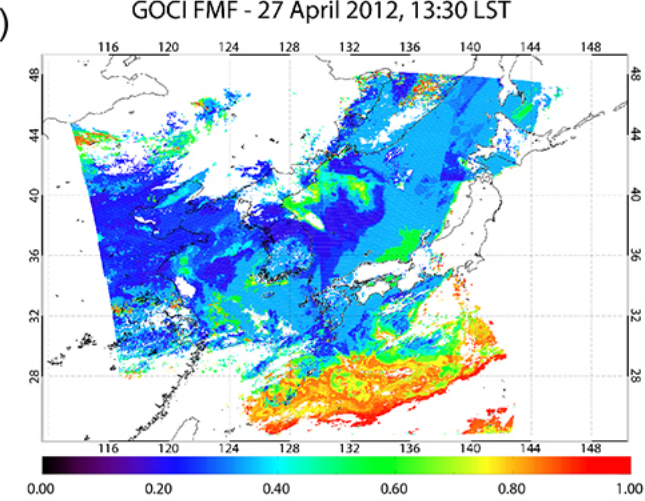

(e)

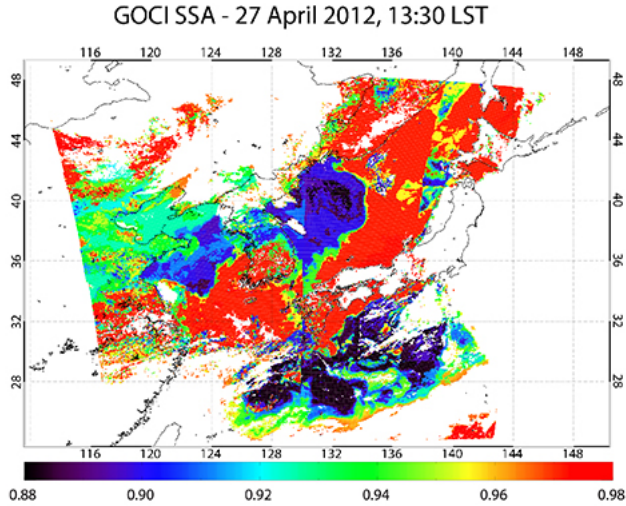

Figure 7. As Fig. 6 except for 27 April 2012.

sively over East Asia (Redemann et al., 2003; Schmid et al., 2003; S. W. Kim et al., 2007). Although the campaign was limited to the spring season, it has the advantage of abundant ground-based observations over Korea and Japan. During the campaign, a total of 40 sun photometers were deployed at urban sites and coastal sites. Over the urban areas of Seoul and Osaka, in particular, distances between AERONET sites are about $10 \mathrm{~km}$, which makes validation of satellite data possible at high spatial resolution.

MODIS onboard Aqua and Terra provides state-of-theart global aerosol properties, and its aerosol retrieval algo- (b)

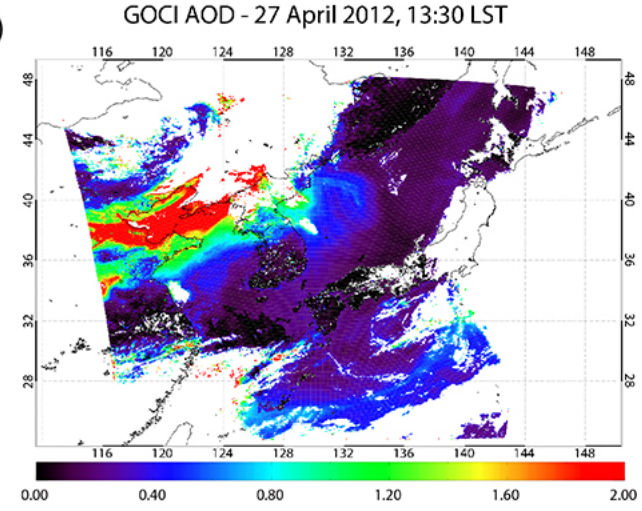

(d)

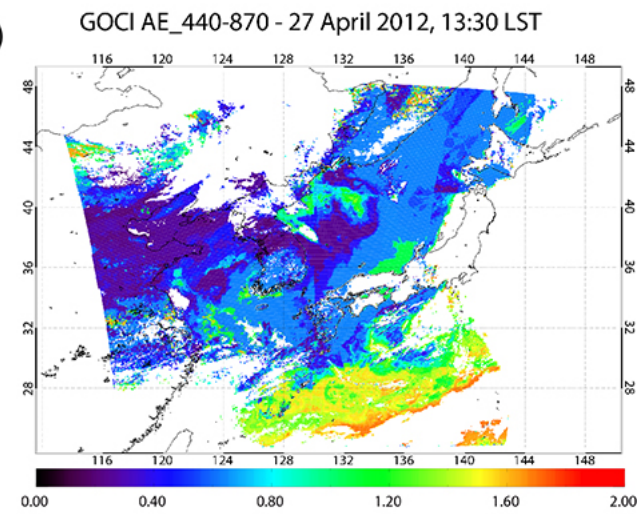

(f)

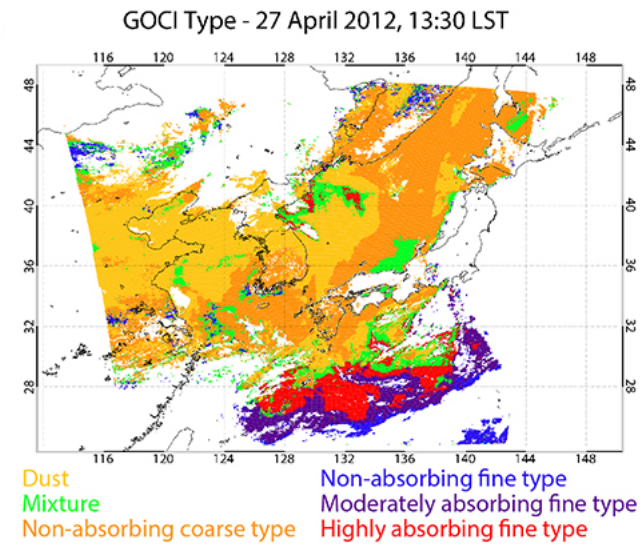

rithms have been developed and improved continuously (Remer et al., 2005; Levy et al., 2007; Hsu et al., 2006). Recently, an updated version was released as C6 (Levy et al., 2013; Hsu et al., 2013). MODIS aerosol products consist of Dark Target (DT) over both ocean and land and Deep Blue (DB) products over land only. Their validation against AERONET showed good agreement globally (Levy et al., 2013; Sayer et al., 2013). Because the validation of GOCI using AERONET is limited in spatial coverage, intercomparison using the satellite-based MODIS data set is also performed for evaluating the GOCI product. 

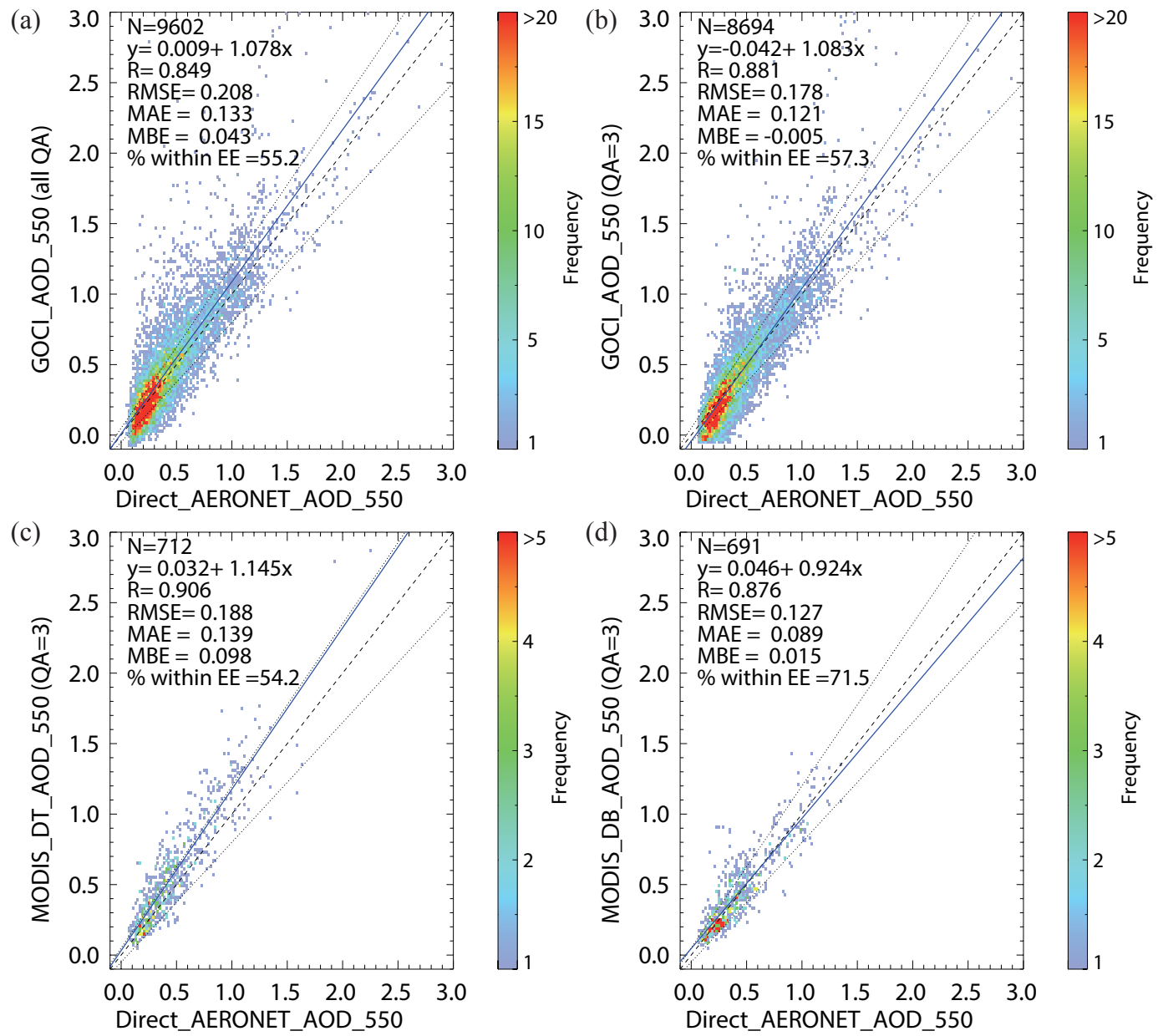

Figure 8. Comparison of AOD between AERONET and (a) GOCI for all QA, (b) GOCI for QA = 3 only, (c) MODIS DT, and (d) MODIS DB. Colored pixels represent a bin size of 0.02 . The blue solid line is the linear regression line. Black dashed and dotted lines denote the one-to-one and expected error lines, respectively.

Therefore, GOCI YAER AOD at $550 \mathrm{~nm}, \mathrm{FMF}$ at $550 \mathrm{~nm}$, SSA at $440 \mathrm{~nm}$, and AE between 440 and $870 \mathrm{~nm}$ are evaluated using both the ground-based AERONET and satellitebased MODIS data sets.

\subsection{Validation conditions between ground-based AERONET and satellite-based GOCI and MODIS}

For the validation, 38 AERONET sites are selected, which have at least 20 days of observations. The current Level 2.0 version 2 direct-sun all points observation products, inversion products, and the spectral deconvolution algorithm (SDA) products are used in this study (Holben et al., 1998; O'Neill et al., 2003; Dubovik and King, 2000). From the direct sun measurement, AOD and Ångström exponent are used. The validation for FMF is done using both inversion and SDA products, while the validation for SSA is done using inversion products. Note that the almucantar observation is only possible when the solar zenith angle is greater than $50^{\circ}$ (Dubovik et al., 2000), so inversion data are unavailable near noon.

Aerosol data from GOCI and AERONET are collocated temporally and spatially for the comparison. The groundbased AERONET observes the sun/sky radiance at intervals of a few minutes at a fixed location, while GOCI observes aerosol over East Asia at hourly intervals. GOCI pixels within $25 \mathrm{~km}$ of an AERONET site are averaged, and AERONET data within $30 \mathrm{~min}$ from GOCI observation time are averaged. Comparison is carried out when at least one pixel of GOCI and one temporal value of AERONET exist. Note that AERONET does not observe AOD at $550 \mathrm{~nm}$ directly; therefore it is interpolated from other channels using a quadratic fit on a log-log scale (Eck et al., 1999). The colocation condition between AERONET and MODIS is the same as for GOCI. Note that validation of MODIS using AERONET is performed for AOD only. 


\subsection{Intercomparison conditions between MODIS and GOCI}

The different characteristics of MODIS and GOCI as LEO and GEO sensors, respectively, need to be considered when intercomparison is performed. Spatial colocation is based on the fixed grid scale over the GOCI observation area, divided into $0.2^{\circ} \times 0.2^{\circ}$ latitude-longitude resolution grid cells. Therefore, MODIS and GOCI data within the same fixed grid are separately averaged, and then matched spatially.

Temporal colocation is based on the MODIS observation time. MODIS Level 2 aerosol data are provided as granules, and the maximum difference in scan time in one granule is about $5 \mathrm{~min}$. The maximum difference in GOCI scan time for one scene is about $30 \mathrm{~min}$, and GOCI scans the observation area every hour. Therefore, two GOCI scenes within $1 \mathrm{~h}$ centered on the MODIS overpass time are interpolated to the MODIS time, and are collocated with MODIS temporally.

\subsection{Validation of AOD}

The validation involves use of the linear regression equation, and validation metrics including the Pearson's linear correlation coefficient $(R)$, root mean square error (RMSE), mean absolute error (MAE), mean bias error (MBE), and the ratio within expected error (\% within EE). Note that MBE and MAE are the mean of differences and absolute differences of value between AERONET and GOCI, respectively. The range of expected error (EE) of AOD is adopted from MODIS DT over land.

Figure 8 compares AOD from GOCI, MODIS DT, and MODIS DB algorithms against AERONET at the 38 DRAGON AERONET sites. Note that only $Q A=3$ data of MODIS DT and DB AOD are used for validation. A total of 9602 data points are matched with GOCI for all QA values, and 8694 for only $\mathrm{QA}=3$ data. There is good agreement between AERONET and GOCI with high data counts (red color) gathered near the one-to-one line. Because GOCI pixels with $\mathrm{QA}=3$ are less cloud contaminated than those with all QA values, there are fewer overestimated pixels from the GOCI $\mathrm{QA}=3$ set. Thus, all validation criteria show better results for $\mathrm{QA}=3$ than for all QA except for the $y$-intercept of the linear regression line. Most comparison points are concentrated within the EE and immediately below EE in AERONET AOD $<0.4$, but large positive biases are observed for AERONET AOD > 0.4, which result in the increase of the $y$-intercept for all QA. Such pixels seem to be contaminated by cloud so, in general, have QA less than 3. Therefore, when only $\mathrm{QA}=3$ pixels are compared with AERONET, the $y$ intercept has a more negative value of -0.042 than for all QA (0.009). The correlation coefficient for AOD between AERONET and GOCI $(\mathrm{QA}=3)$ is 0.881 , which is similar to that of MODIS DT (0.906) and DB (0.876). For slope, RMSE, MBE, and \% within EE, GOCI is better than that of
MODIS DT. Munchak et al. (2013) described that MODIS DT Collection 6 AOD is biased high over urban surfaces, and it is suspected due to the inaccurate surface reflectance over urban in the MODIS DT operational retrievals. Otherwise, the enhanced MODIS DB algorithm (Collection 6) shows the best result, which controls surface reflectance differently according to surface type, giving high accuracy regardless of surface type (Hsu et al., 2013). The ratio within EE of MODIS DB against AERONET is $71.5 \%$ for all AERONET sites, which is greater than for GOCI $(57.3 \%)$.

Results of intercomparison of AOD between GOCI and MODIS are shown in Fig. 9. Note that ocean pixels near most coastal sites are classified as turbid water and retrieved using the land algorithm. Thus, it is hard to validate the GOCI ocean algorithm using AERONET, but it is possible using MODIS DT ocean AOD. Intercomparison of the ocean AOD of MODIS DT and GOCI shows good agreement $(R=0.939)$. The slope of the regression line is 1.019 and the $y$-intercept is 0.039 . Both algorithms consider wind-speeddependent surface reflectance. Because the ocean surface is darker than the land surface, it is easier to detect cloud pixels over ocean and so there are fewer overestimation points for GOCI. The GOCI AOD over ocean is retrieved from the ocean algorithm over clear water and the land algorithm over turbid water (or heavy aerosol loading). The AOD over turbid water pixels is not retrieved in the MODIS DT ocean algorithm, so direct comparison over turbid water is impossible (Lee et al., 2010b).

A common feature of comparisons of GOCI products using MODIS DT and DB over land is that there are more scattered points above the one-to-one line than in comparisons between AERONET and GOCI. Because cloud is effectively cleared in AERONET Level 2 data, most collocated cases with AERONET are in fact cloud-free cases. MODIS DT and DB use the characteristics of cloud in visible and infrared (IR) wavelengths for cloud screening, but there are no IR channels in GOCI. As a result, cloud screening is carried out using visible-near IR channels only. It is more difficult to distinguish the cloud signal clearly over land using only visible characteristics because of bright surface reflectance, especially for urban surfaces. If cloud is not removed correctly, its signal is considered as aerosol, and AOD is overestimated. This explains the greater number of pixels scattered above the one-to-one line in both comparisons over land. GOCI YAER AOD over land is better correlated with MODIS DB $(R=0.866)$ than DT $(R=0.827)$, and the linear regression line over land between GOCI and MODIS DB is also closer to the one-to-one line than with MODIS DT. Although the surface reflectance calculation of GOCI YAER algorithm is not exactly the same as that of MODIS DB algorithm, the methodology of GOCI YAER algorithm is closer with MODIS DB than MODIS DT. Precalculated surface reflectance database is applied over arid/semiarid surfaces, which has been used in the previous MODIS DB algorithm (Hsu et al., 2004, 2006) and enhanced MODIS 

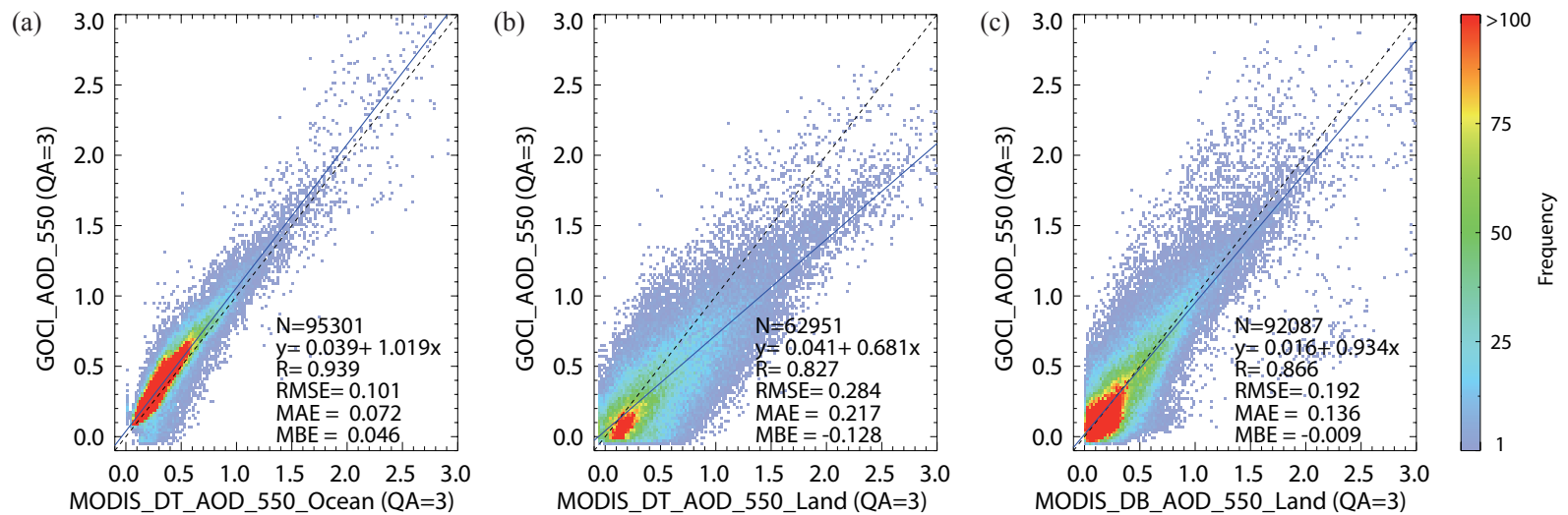

Figure 9. Comparison of AOD between (a) MODIS DT and GOCI over ocean, (b) MODIS DT and GOCI over land, and (c) MODIS DB and GOCI over land. Color pixels represent a bin size of 0.02 . The blue solid line is the linear regression line. The black dashed line is the one-to-one line.

DB algorithm (Hsu et al., 2013). However, the enhanced MODIS DB algorithm used in this study for validation adopts three different methods according to land surface types. Over vegetated land surfaces, it takes the spectral relationship in surface reflectance between visible and longer wavelengths, which is used in the MODIS DT algorithm. Over urban/builtup and transitional regions, a hybrid approach is applied by combining the Deep Blue surface database with the angular shapes of surface bidirectional reflectance distribution function (BRDF). Aerosol model constructions of three algorithms are similar as the model considers fine/coarse and absorbing/non-absorbing characteristics. However, the MODIS DB uses reflectance at $412 \mathrm{~nm}$ for retrieval, similar to GOCI, while MODIS DT does not. Inversion procedures of three algorithms are not significantly different. Both MODIS DT and DB retrieve spectral AODs (470 and $660 \mathrm{~nm}$ for DT; 412, 470, and $660 \mathrm{~nm}$ of DB), interpolated to the AOD at $550 \mathrm{~nm}$. However, the GOCI YAER algorithm retrieves AOD at $550 \mathrm{~nm}$ directly from other channels' reflectance. Hence, the tendency and accuracy of retrieved AOD from GOCI are closer to MODIS DB than DT.

\subsection{Validation of Ångström exponent, fine-mode fraction, and single-scattering albedo}

The GOCI YAER AE, FMF, and SSA are determined from the three selected aerosol models used in retrieving the AOD. Therefore, the possible product retrieval ranges are limited by the aerosol models. AE, FMF, and SSA can be retrieved in the ranges of $0.0930-1.744,0.156-0.956$, and $0.871-0.970$, respectively.

Figure 10a and $\mathrm{b}$ show the comparison of $\mathrm{AE}$ between AERONET and GOCI. The correlation coefficient is 0.594 in Fig. 10a, which is significantly lower than for the AOD comparison (0.881). The difference in spectral aerosol signal does not vary much with aerosol model when AOD is low, so the error of AE can be large at low AOD. When AOD is less than 0.3, the value of AE is about 1.3 for AERONET, but about 0.7 for the GOCI retrieval; thus when these points are removed, the correlation coefficient increases to 0.678 in Fig. 10b. AE is underestimated from GOCI compared with AERONET $(\mathrm{MBE}=-0.316)$ for the whole range although highest density of points from AERONET and GOCI coincide.

Although the MODIS DT AE over land can be calculated using spectral AOD at 470 and $660 \mathrm{~nm}$, intercomparison of the AE between MODIS DT and GOCI is not done over land in this study. Levy et al. (2010) reported that AE is not available globally at sufficient quantitative accuracy; therefore it was removed from the operational C6 DT products (Levy et al., 2013). Therefore, comparison is only performed over the ocean. The MODIS DT AOD over the ocean is retrieved at 550 and $860 \mathrm{~nm}$, so the AE between these two channels is compared with the GOCI AE in Fig. 10c. Over the ocean both GOCI and MODIS DT assume Fresnel reflectance with wind speed dependence for the surface reflectance, and the surface reflectances is similar between GOCI and MODIS DT over, and the surface reflectance of ocean is lower than that of land. Therefore, high counts are well matched and the RMSE and $\operatorname{MBE}(0.357$ and 0.064 , respectively) are better than those of AERONET versus GOCI (0.439 and -0.316 , respectively) although the correlation coefficient is much lower at 0.376 .

FMF is provided directly from SDA AERONET, or calculated using the almucantar retrievals of fine AOD and the total AOD at $675 \mathrm{~nm}$ from AERONET inversions. Both AERONET FMF products are compared with the GOCI YAER FMF in Fig. 11a and b. Note that both comparisons are for AERONET AOD $>0.3$. The correlation coefficients are 0.698 and 0.750 for SDA and inversion AERONET, respectively. These are higher values than for AE validation, but less than for AOD validation. High counts of AERONET are grouped around 0.9-1.0, but those of GOCI are grouped at 0.8 . GOCI FMF is underestimated compared 

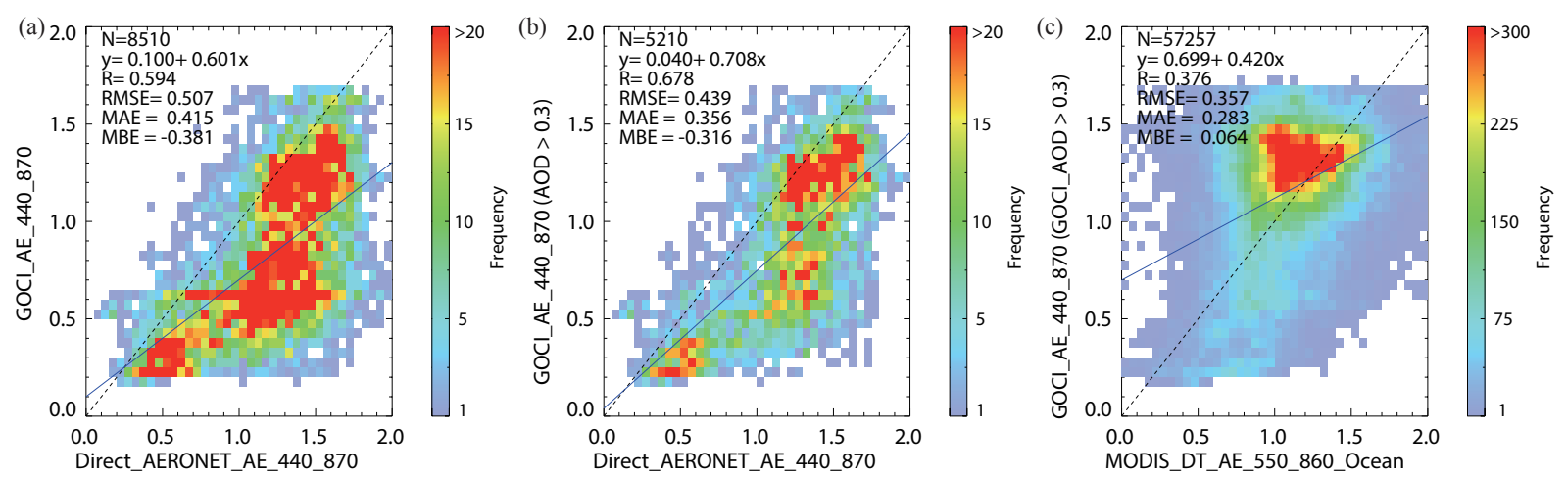

Figure 10. Comparison of AE between direct AERONET and GOCI for (a) the whole AERONET AOD range, and (b) only for AERONET AOD > 0.3. (c) AE intercomparison between MODIS DT and GOCI over ocean only for GOCI AOD > 0.3. Colored pixels represent a bin size of 0.05. Wavelengths of Ångström exponents are 440 and $870 \mathrm{~nm}$ for AERONET and GOCI, and 550 and $860 \mathrm{~nm}$ for MODIS DT over ocean. Dashed and solid lines denote the same as Fig. 9.
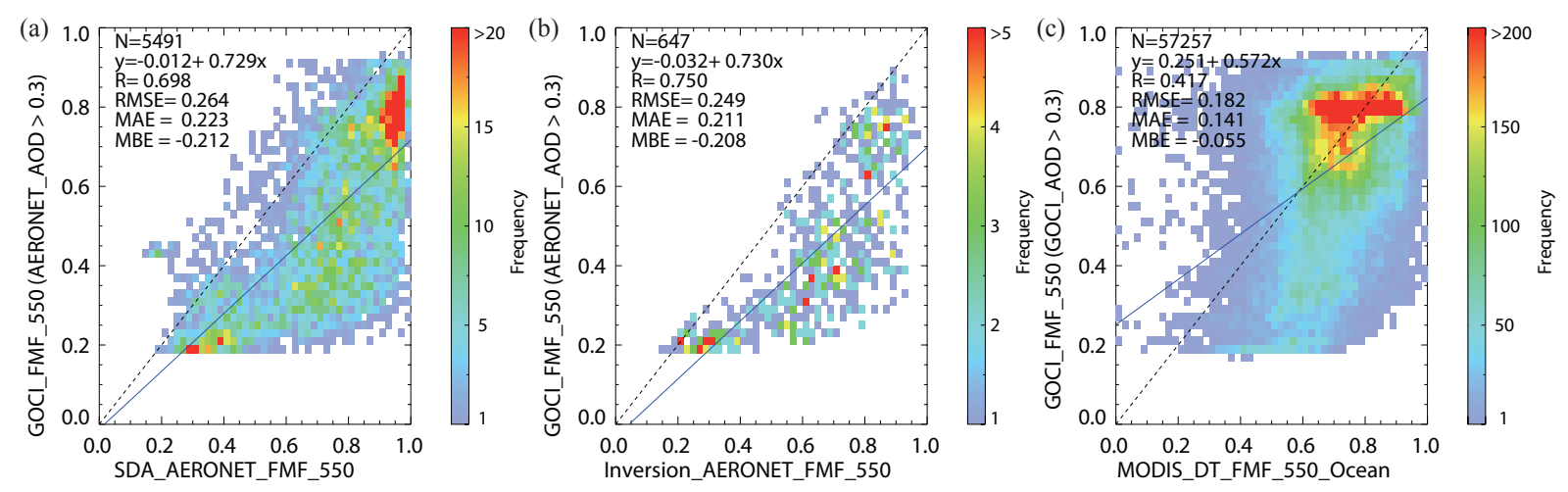

Figure 11. Comparison of FMF between (a) SDA AERONET and GOCI, and (b) inversion AERONET and GOCI only for AERONET AOD $>0.3$. (c) FMF intercomparison between MODIS DT and GOCI over ocean only for GOCI AOD > 0.3. Colored pixels represent a bin size of 0.05. Dashed and solid lines denote the same as Fig. 9.

with AERONET for the whole FMF range. The MBE values are -0.212 and -0.208 , respectively.

The intercomparison of FMF between MODIS DT and GOCI over the ocean is shown in Fig. 11c. The correlation is better $(R=0.417$ and $\mathrm{RMSE}=0.182)$ than for of $\mathrm{AE}$ $(R=0.376$ and $\mathrm{RMSE}=0.357)$. The validation results for FMF are analogous to those of AE because both parameters are sensitive to the particle size in visible wavelengths.

Figure 12 shows the results of comparing SSA between AERONET inversion and GOCI. Only 617 points are collocated temporally and spatially because Level 2 AERONET SSA is only provided for AOD $(440 \mathrm{~nm})>0.4$ and almucantar observation is performed when the solar zenith angle is greater than $50^{\circ}$ (Dubovik and King, 2000). The correlation coefficient is 0.353 , which is the lowest among the GOCI products. Nevertheless, the accuracy of GOCI SSA is comparable with that of OMI SSA over East Asia. According to Jethva et al. (2014), the correlation coefficient between AERONET and OMI SSA is 0.406. They also showed that 44.91 and $70.29 \%$ of OMI SSA data are within differ- ences of \pm 0.03 and \pm 0.05 with respect to AERONET. GOCI SSA shows higher ratios than OMI, 69.0 and $86.9 \%$, for the same criteria over Northeast Asia. A preliminary redundancy test (Lee et al., 2012), which showed that GOCI SSA may be underestimated at high SSA $(\sim 0.95)$ and overestimated at low SSA $(\sim 0.85)$, is consistent with the results of GOCI SSA validation against AERONET. The difference between absorbing and non-absorbing aerosols is significant in the ultraviolet (UV) and shorter visible (blue) wavelengths, and weak at longer visible (green and red) wavelengths. GOCI YAER algorithm is optimized for AOD retrieval using aerosol model composition classified by FMF and SSA. In the next generation GOCI-2 mission to be launched in 2019, SSA can be retrieved more accurately utilizing the UV channel.

GOCI AE and SSA product qualities could also be compared with other previous studies while the region and period are different. Global MODIS DT Ångström exponent validation results with AERONET were presented in Levy et al. (2010) and Levy et al. (2013) over land and ocean, 


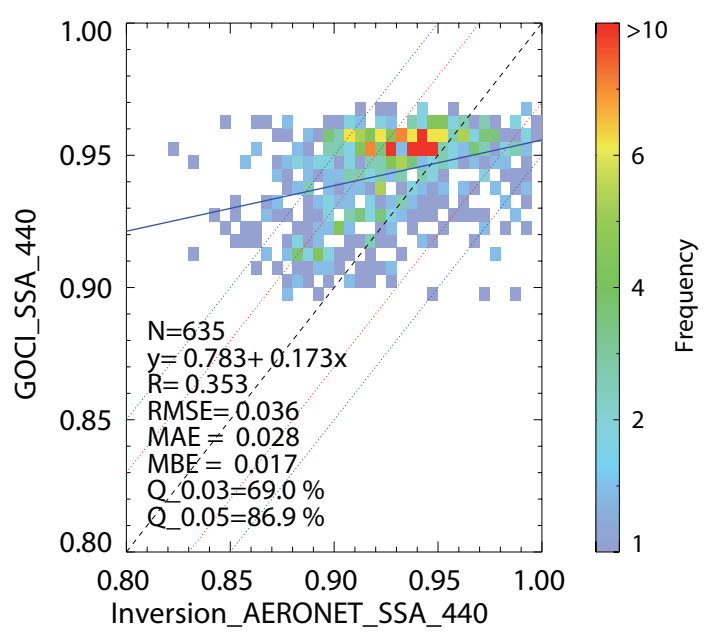

Figure 12. Comparison of SSA between inversion AERONET and GOCI. Colored pixels represent a bin size of 0.005. Dashed and solid lines denote the same as Fig. 9. Red and blue dotted lines denote the \pm 0.03 and \pm 0.05 ranges, respectively.

respectively. Levy et al. (2010) compared the MODIS DT Collection 5 Ångström exponent between 470 and $650 \mathrm{~nm}$ (AE_470_650) and AERONET AE_470_650 over land, resulting in $R$ of 0.554 and a linear regression equation with MODIS AE_470_660 $=0.6471 \times$ AERONET AE_470_660 +0.3342 . According to Levy et al. (2013), the MODIS DT Collection 6 Ångström exponent between 550 and $870 \mathrm{~nm}$ (AE_550_870) shows more higher accuracy over ocean $(R=0.612$ and a linear regression equation with MODIS AE_550_870 $=0.686 \times$ AERONET AE_550_870 + 0.47). MODIS DB Collection 6 Ångström exponent (over land) shows similar accuracy with GOCI YAER Ångström exponent ( $R=0.45$ for all AOD and $R=0.68$ when AOD is greater than 0.3). These results are similar to those of GOCI YAER AE validation $(R=0.594$ for all AOD and $R=0.678$ when AOD is greater than 0.3).

Aerosol optical properties such as Ångström exponent and single-scattering albedo retrieved from the Polarization and Directionality of Earth's Reflectance (POLDER) instrument on-board the Polarization and Anisotropy of Reflectances for Atmospheric Sciences coupled with Observations from a Lidar (PARASOL) satellite shows more accurate results. Hasekamp et al. (2011) described that AE retrieval using polarization measurement shows higher accuracy $(R=0.85)$ than using intensity-only retrieval $(R=0.62)$. Generalized Retrieval of Aerosol \& Surface Properties (GRASP) algorithm using POLDER (Dubovik et al., 2011; Kokhanovsky et al., 2015) shows higher accuracy in SSA $(R=0.93)$ when AOD is greater than 0.4. These results mean that more information such as polarization and multi-angle observation can improve retrieval accuracy of aerosol optical properties. In conclusion, GOCI AE, FMF, and SSA show lower accu- racy than AOD. Nevertheless, these values can be useful for qualitative studies, although not for quantitative studies.

\section{Error analysis of GOCI YAER AOD}

Uncertainties in surface reflectance, assumed aerosol model, cloud masking, and geometry result in systematic errors in the retrieved AOD. In this section, the difference in AOD between GOCI and AERONET is analyzed to quantify the respective error sources affecting the accuracy of GOCI AOD.

The difference in AOD between GOCI and AERONET is shown in Fig. 13a as a function of AERONET AOD. The 16$84 \%$ range for each bin widens as AOD increases, as with satellite products. GOCI AOD has a negative bias of -0.1 against AERONET for AERONET AOD $<0.4$, while there is no consistent bias but a skewed distribution toward the positive differences for AERONET AOD > 0.9. Main uncertainties in low AOD and high AOD are linked to uncertainties in surface reflectance and assumptions about aerosol microphysical properties, respectively (Sayer et al., 2013). Levy et al. (2010) also described that systematic bias for low AOD results from overestimating the surface reflectance in the visible channels. Therefore, the minimum reflectivity technique can overestimate surface reflectance due to contamination by the remaining cloud or aerosol, resulting in negative bias at low AOD. On the other hand, the accuracy at high AOD can be affected by the assumed aerosol model or cloud masking. An insignificant bias of the median points supports the validity of the assumed aerosol model, but a positive skewed distribution can be attributed to the remaining cloud contamination due to cloud masking using visible channels only. It is difficult to distinguish aerosol and cirrus cloud without information from IR wavelengths (Lee et al., 2013).

The next comparison is the difference in AOD between GOCI and AERONET plotted against the scattering angle in Fig. 13b. GOCI AOD is underestimated at scattering angles near 115 and $140^{\circ}$ and overestimated at $145^{\circ}$ and above $160^{\circ}$. Scattering angle is calculated using solar zenith angle, satellite zenith angle, and relative azimuth angle. GOCI is on geostationary orbit; therefore satellite zenith and azimuth angles are fixed. Therefore, relative azimuth angle between sun and satellite varies according to local standard time only. Solar zenith angle varies according to local standard time and season. Scattering angle contains such complicated error sources, which makes the scattering angle dependency of AOD difference between GOCI and AERONET difficult to interpret; therefore AOD error analyses according to solar zenith angle and relative azimuth angle are also presented.

GOCI AOD errors according to solar zenith angle as Fig. $13 \mathrm{c}$ are close to zero at $30,40,50$, and $60^{\circ}$ solar zenith angle, and show fluctuating pattern between them. LUT node points of solar zenith angle are constructed at $10^{\circ}$ interval, and linear interpolation to observed solar zenith angles in inversion procedure could cause this error pattern. The fluctuation tendency of error as underestimation at scattering angles 
(a)

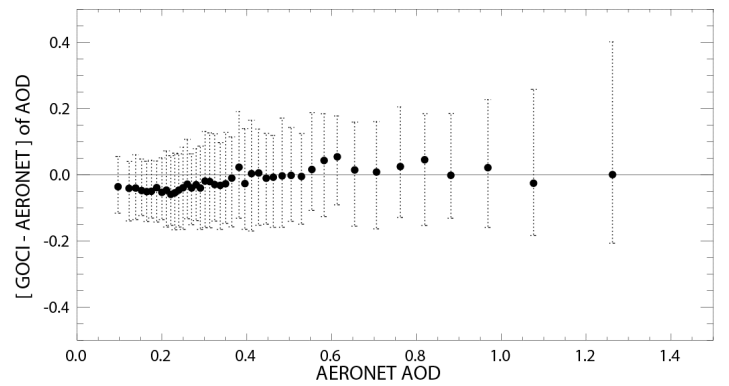

(c)

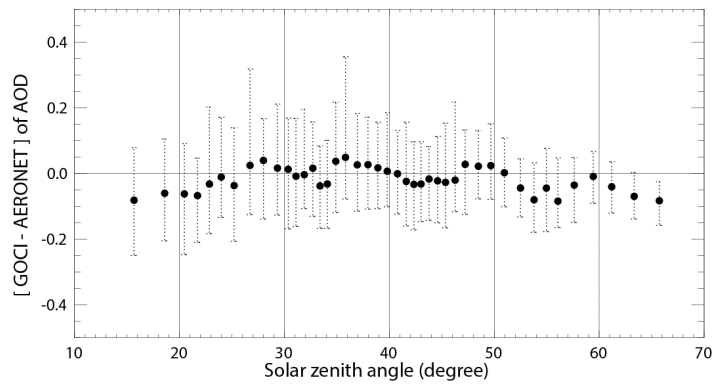

(e)

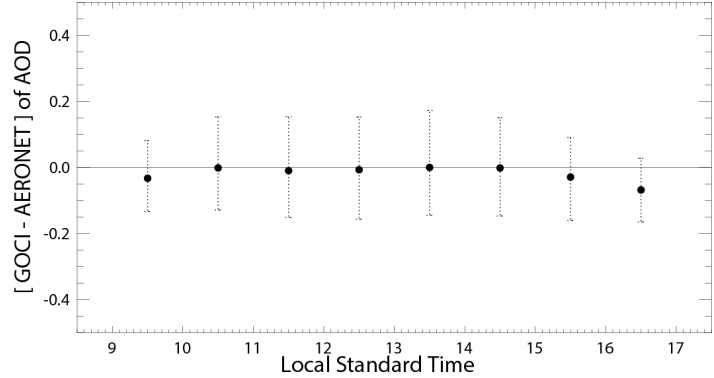

(b)

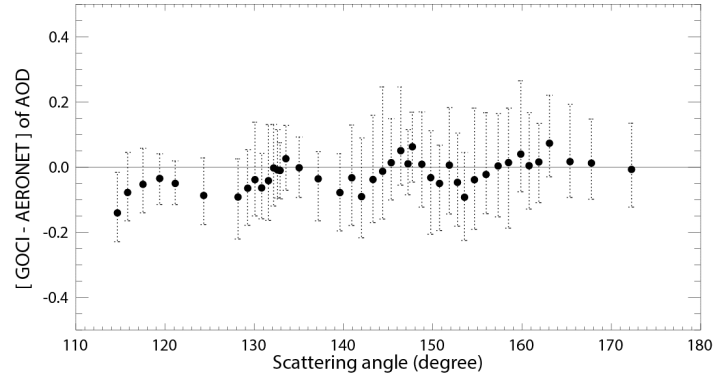

(d)

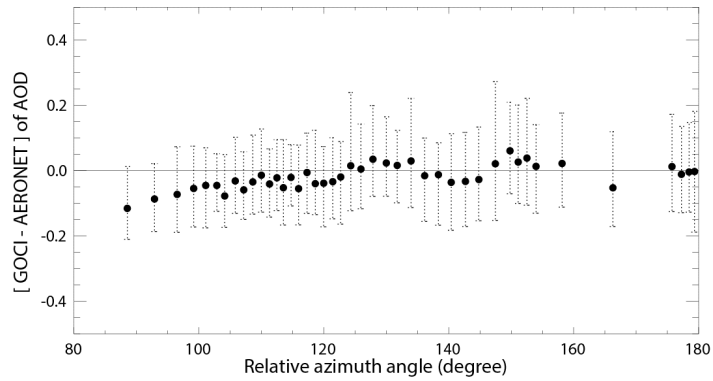

(f)

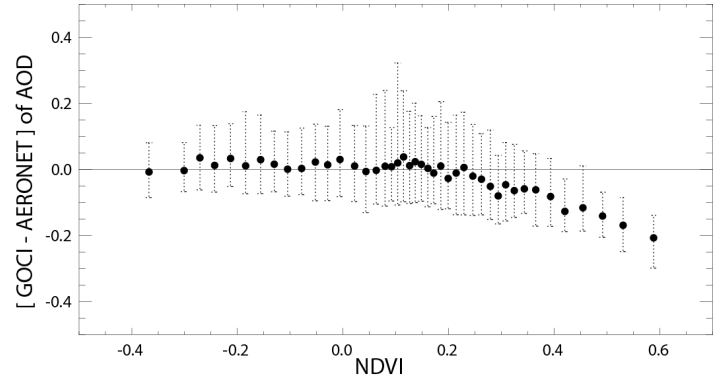

Figure 13. Difference in AOD between GOCI and AERONET according to (a) AERONET AOD, (b) scattering angle, (c) solar zenith angle, (d) relative azimuth angle, (e) local standard time, and (f) NDVI. Each point is the median value from 200 collocated data sorted in ascending order of each $x$ axis value except for local standard time. Lower and upper bounds of the error bar at each point correspond to the 16 and $84 \%$ points of each bin, respectively.

could also be caused by the interpolation error in the inversion procedure. Subdivision of $5^{\circ}$ interval for node point of LUT calculation or online calculation could improve this interpolation error (Jeong et al., 2016).

Error tendency according to relative azimuth angle as Fig. 13d shows less fluctuant shape, and underestimation at low relative azimuth angle. Both conditions of low azimuth angle and high solar zenith angle correspond to the early morning or late afternoon as local standard time. Therefore, errors analyzed according to the fixed local standard time as shown in Fig. 13e show underestimation at 09:30, 15:30, and 16:30. Plane-parallel atmosphere approximation or scalar calculation in the RTM could result in less accurate Rayleigh scattering calculation for surface reflectance using the minimum reflectivity technique.

The method for determining surface reflectance is applied equally to all pixels regardless of surface type. To test the accuracy as a function of surface type, the normalized difference vegetation index (NDVI) is adopted, de- fined as $\left(\rho_{\mathrm{TOA}}(865 \mathrm{~nm})-\rho_{\mathrm{TOA}}(660 \mathrm{~nm})\right) /\left(\rho_{\mathrm{TOA}}(865 \mathrm{~nm})\right.$ $\left.+\rho_{\mathrm{TOA}}(660 \mathrm{~nm})\right)$. Generally, it is negative over ocean and positive over land. It is close to 1 when the surface is green because of vegetation growth, while it is close to zero over less green areas. Figure $13 \mathrm{f}$ shows the difference in AOD between GOCI and AERONET plotted against NDVI. Note that negative NDVI is possible when GOCI ocean pixels are collocated with AERONET at coastal sites. The difference is small $(0-0.05)$ and the bias is for low NDVI $(-0.4$ to 0.1 ). However, the difference decreases linearly from 0.05 to -0.2 as NDVI increases from 0.1 to 0.6 , due to the limitation in minimum reflectivity technique with a search window of 1 month during the dynamic vegetation change in the spring season and its reference at $412 \mathrm{~nm}$ channel. AOD is significantly underestimated by GOCI with increasing vegetation cover, thus surface type must be considered to improve the algorithm as included in the enhanced MODIS DB algorithm (Hsu et al., 2013). Additionally, this may be partially due to the most densely vegetated surfaces in both Korea 
and Japan being forested mountains. Because aerosol concentration decreases exponentially as altitude increases generally, any GOCI retrievals made over the hills or mountains have lower AOD than the values located in the valley or lowaltitude-level area. NDVI is largest over the forested mountain slopes which extend to the upper part of the aerosol layer, therefore the GOCI retrievals are underestimated as NDVI increases.

\section{Conclusions}

Since its development the prototype over-ocean GOCI YAER algorithm over the ocean (Lee et al., 2010b) was further developed to include nonspherical aerosol models for better performance for dust cases (Lee et al., 2012). However, the algorithm has only been tested using MODIS data, and limited to ocean surfaces. Here, based on the heritage, the GOCI YAER algorithm is extended to land surfaces and tested using real GOCI data. GOCI has the advantages of high spatial $(500 \mathrm{~m} \times 500 \mathrm{~m})$ and temporal (hourly) resolution using eight channels in visible and near-infrared wavelengths. Therefore, other properties such as FMF, AE, and SSA as well as AOD can be retrieved at a $6 \mathrm{~km} \times 6 \mathrm{~km}$ resolution.

Different surface reflectance assumptions and channels are applied for the land and ocean. Turbid water is detected according to $\Delta \rho_{660}$, and the land algorithm is applied to it for better performance. In addition, nonsphericity and dynamical properties of aerosol are reflected in the aerosol models.

The DRAGON-NE Asia 2012 campaign in spring has enabled the evaluation of GOCI YAER products over 38 sites in Korea and Japan using AERONET data and MODIS over East Asia. AOD from the GOCI YAER shows good agreement with AERONET with a correlation coefficient of 0.881 , which is similar to that of MODIS DT $(R=0.906)$ and DB ( $R=0.876)$. The fraction of AOD data falling within the expected error for GOCI is $57.3 \%$, which is worse than MODIS DB $(71.5 \%)$ but similar to MODIS DT $(54.2 \%)$. In the intercomparison between GOCI and MODIS, GOCI and MODIS DT show good agreement over ocean with high correlation $(R=0.939)$. Over land, GOCI YAER shows better agreement and less bias with MODIS DB $(R=0.866, \mathrm{RMSE}=$ $0.192)$ than MODIS DT $(R=0.827$, RMSE $=0.284)$ likely due in part to similar retrieval conditions in both GOCI and MODIS DB. For size parameters such as AE and FMF, GOCI agrees less well with AERONET $(R=0.594-0.750)$ and tends to underestimate $(\mathrm{MBE}=-0.381$ to -0.208$)$. Over ocean, the comparison of size parameters between GOCI and MODIS DT shows significantly poorer agreement $(R=$ $0.376-0.417$ ), but data points with high frequency are well matched. For the SSA, GOCI shows low correlation of 0.353 with AERONET, but the range of SSA (0.90-0.95) is well matched each other. In conclusion, GOCI YAER AOD shows high accuracy against MODIS, and other aerosol parameter products can be used qualitatively, although their accuracy is less than AOD.

From the error analysis, GOCI YAER AOD shows a negative bias of -0.1 for low AOD $(<0.4)$, and the negative bias increases as NDVI becomes higher. It is necessary to improve the accuracy of surface reflectance over vegetated areas for the next version, and possibly account for the elevation of forested mountains relative to the aerosol vertical profile.

The current version of LUT was calculated by using a scalar RTM, libRadtran; this RTM is less accurate for calculating Rayleigh scattering for the short visible wavelengths ( $\sim 400 \mathrm{~nm})$. A vector RTM might be helpful in improving the accuracy of the GOCI YAER algorithm in the future. The current validation period is limited to spring season in 2012, and thus the seasonal dependence of accuracy is not presented in this study. Nearly 5 years of GOCI data have been accumulated since March 2011, which will allow longterm validation and analysis to be carried out to investigate retrieval accuracies and uncertainties in the near future.

Acknowledgements. We thank the Korean Institute of Ocean Science and Technology (KIOST) for the development and application of GOCI in this research. We also thank all principal investigators and their staff for establishing and maintaining the AERONET sites of the DRAGON-NE Asia 2012 campaign used in this investigation. We also thank the MODIS science team for providing valuable data for this research. This research was supported by the GEMS program of the Ministry of Environment, Korea, and the Eco Innovation Program of KEITI (2012000160002).

Edited by: M. Schulz

\section{References}

Ahn, J. H., Park, Y. J., Ryu, J. H., Lee, B., and Oh, I. S.: Development of Atmospheric Correction Algorithm for Geostationary Ocean Color Imager (GOCI), Ocean Sci. J., 47, 247-259, 2012.

Choi, J. K., Park, Y. J., Ahn, J. H., Lim, H. S., Eom, J., and Ryu, J. H.: GOCI, the world's first geostationary ocean color observation satellite, for the monitoring of temporal variability in coastal water turbidity, J. Geophys. Res.-Oceans, 117, C09004, doi:10.1029/2012JC008046, 2012.

Ciren, P. and Kondragunta, S.: Dust aerosol index (DAI) algorithm for MODIS, J. Geophys. Res.-Atmos., 119, 4770-4792, 2014.

Cox, C. and Munk, W.: Statistics of the sea surface derived from sun glitter, J. Marine Res., 13, 198-227, 1954.

Dubovik, O. and King, M. D.: A flexible inversion algorithm for retrieval of aerosol optical properties from Sun and sky radiance measurements, J. Geophys. Res.-Atmos., 105, 20673-20696, 2000.

Dubovik, O., Smirnov, A., Holben, B. N., King, M. D., Kaufman, Y. J., Eck, T. F., and Slutsker, I.: Accuracy assessments of aerosol optical properties retrieved from Aerosol Robotic Network (AERONET) Sun and sky radiance measurements, J. Geophys. Res.-Atmos., 105, 9791-9806, 2000. 
Dubovik, O., Sinyuk, A., Lapyonok, T., Holben, B. N., Mishchenko, M., Yang, P., Eck, T. F., Volten, H., Munoz, O., Veihelmann, B., van der Zande, W. J., Leon, J. F., Sorokin, M., and Slutsker, I.: Application of spheroid models to account for aerosol particle nonsphericity in remote sensing of desert dust, J. Geophys. Res.Atmos., 111, D11208, doi:10.1029/2005JD006619, 2006.

Dubovik, O., Herman, M., Holdak, A., Lapyonok, T., Tanré, D., Deuzé, J. L., Ducos, F., Sinyuk, A., and Lopatin, A.: Statistically optimized inversion algorithm for enhanced retrieval of aerosol properties from spectral multi-angle polarimetric satellite observations, Atmos. Meas. Tech., 4, 975-1018, doi:10.5194/amt-4975-2011, 2011.

Eck, T. F., Holben, B. N., Reid, J. S., Dubovik, O., Smirnov, A., O'Neill, N. T., Slutsker, I., and Kinne, S.: Wavelength dependence of the optical depth of biomass burning, urban, and desert dust aerosols, J. Geophys. Res.-Atmos., 104, 3133331349, 1999.

Eck, T. F., Holben, B. N., Reid, J. S., O’Neill, N. T., Schafer, J. S., Dubovik, O., Smirnov, A., Yamasoe, M. A., and Artaxo, P.: High aerosol optical depth biomass burning events: A comparison of optical properties for different source regions, Geophys. Res. Lett., 30, 2035, doi:2010.1029/2003GL017861, 2003.

Fukuda, S., Nakajima, T., Takenaka, H., Higurashi, A., Kikuchi, N., Nakajima, T. Y., and Ishida, H.: New approaches to removing cloud shadows and evaluating the $380 \mathrm{~nm}$ surface reflectance for improved aerosol optical thickness retrievals from the GOSAT/TANSO-Cloud and Aerosol Imager, J. Geophys. Res.-Atmos., 118, 13520-13531, 2013.

Hasekamp, O. P., Litvinov, P., and Butz, A.: Aerosol properties over the ocean from PARASOL multiangle photopolarimetric measurements, J. Geophys. Res.-Atmos., 116, D14204, doi:14210.11029/12010JD015469, 2011.

Herman, J. R. and Celarier, E. A.: Earth surface reflectivity climatology at 340-380 nm from TOMS data, J. Geophys. Res.Atmos., 102, 28003-28011, 1997.

Higurashi, A. and Nakajima, T.: Development of a two-channel aerosol retrieval algorithm on a global scale using NOAA AVHRR, J. Atmos. Sci., 56, 924-941, 1999.

Holben, B. N., Eck, T. F., Slutsker, I., Tanre, D., Buis, J. P., Setzer, A., Vermote, E., Reagan, J. A., Kaufman, Y. J., Nakajima, T., Lavenu, F., Jankowiak, I., and Smirnov, A.: AERONET - A federated instrument network and data archive for aerosol characterization, Remote Sens. Environ., 66, 1-16, 1998.

Hsu, N. C., Tsay, S. C., King, M. D., and Herman, J. R.: Aerosol properties over bright-reflecting source regions, IEEE T. Geosci. Remote, 42, 557-569, 2004.

Hsu, N. C., Tsay, S. C., King, M. D., and Herman, J. R.: Deep blue retrievals of Asian aerosol properties during ACE-Asia, IEEE T. Geosci. Remote, 44, 3180-3195, 2006.

Hsu, N. C., Gautam, R., Sayer, A. M., Bettenhausen, C., Li, C., Jeong, M. J., Tsay, S.-C., and Holben, B. N.: Global and regional trends of aerosol optical depth over land and ocean using SeaWiFS measurements from 1997 to 2010, Atmos. Chem. Phys., 12, 8037-8053, doi:10.5194/acp-12-8037-2012, 2012.

Hsu, N. C., Jeong, M. J., Bettenhausen, C., Sayer, A. M., Hansell, R., Seftor, C. S., Huang, J., and Tsay, S. C.: Enhanced Deep Blue aerosol retrieval algorithm: The second generation, J. Geophys. Res.-Atmos., 118, 9296-9315, 2013.
IPCC: Climate Change 2013: The Physical Science Basis. Contribution of Working Group I to the Fifth Assessment Report of the Intergovernmental Panel on Climate Change, Cambridge University Press, Cambridge, United Kingdom and New York, NY, USA, 2013.

Jackson, J. M., Liu, H. Q., Laszlo, I., Kondragunta, S., Remer, L. A., Huang, J. F., and Huang, H. C.: Suomi-NPP VIIRS aerosol algorithms and data products, J. Geophys. Res.-Atmos., 118, 1267312689, 2013.

Jeong, U., Kim, J., Ahn, C., Torres, O., Liu, X., Bhartia, P. K., Spurr, R. J. D., Haffner, D., Chance, K., and Holben, B. N.: An optimal-estimation-based aerosol retrieval algorithm using OMI near-UV observations, Atmos. Chem. Phys., 16, 177-193, doi:10.5194/acp-16-177-2016, 2016.

Jethva, H., Torres, O., and Ahn, C.: Global assessment of OMI aerosol single-scattering albedo using ground-based AERONET inversion, J. Geophys. Res.-Atmos., 119, 9020-9040, 2014.

Kang, G., Youn, H. S., Choi, S. B., and Coste, P.: Radiometric calibration of COMS geostationary ocean color imager, in: Sensors, Systems, and Next-Generation Satellites X, Proc. SPIE, Stockholm, Sweden, doi:10.1117/12.689888, 2006.

Kaufman, Y. J., Tanre, D., Remer, L. A., Vermote, E. F., Chu, A., and Holben, B. N.: Operational remote sensing of tropospheric aerosol over land from EOS moderate resolution imaging spectroradiometer, J. Geophys. Res.-Atmos., 102, 17051-17067, 1997a.

Kaufman, Y. J., Wald, A. E., Remer, L. A., Gao, B. C., Li, R. R., and Flynn, L.: The MODIS 2.1-mu m channel - Correlation with visible reflectance for use in remote sensing of aerosol, IEEE T. Geosci. Remote, 35, 1286-1298, 1997 b.

Kim, J., Lee, J., Lee, H. C., Higurashi, A., Takemura, T., and Song, C. H.: Consistency of the aerosol type classification from satellite remote sensing during the Atmospheric Brown Cloud-East Asia Regional Experiment campaign, J. Geophys. Res.-Atmos., 112, D22S33, doi:10.1029/2006JD008201, 2007.

Kim, J., Yoon, J. M., Ahn, M. H., Sohn, B. J., and Lim, H. S.: Retrieving aerosol optical depth using visible and mid-IR channels from geostationary satellite MTSAT-1R, Int. J. Remote Sens., 29, 6181-6192, 2008.

Kim, S. W., Yoon, S. C., Kim, J., and Kim, S. Y.: Seasonal and monthly variations of columnar aerosol optical properties over east Asia determined from multi-year MODIS, LIDAR, and AERONET Sun/sky radiometer measurements, Atmos. Environ., 41, 1634-1651, 2007.

Knapp, K. R., Vonder Haar, T. H., and Kaufman, Y. J.: Aerosol optical depth retrieval from GOES-8: Uncertainty study and retrieval validation over South America, J. Geophys. Res.-Atmos., 107, 4055, doi:10.1029/2001JD000505, 2002.

Knapp, K. R., Frouin, R., Kondragunta, S., and Prados, A.: Toward aerosol optical depth retrievals over land from GOES visible radiances: determining surface reflectance, Int. J. Remote Sens., 26, 4097-4116, 2005.

Koelemeijer, R. B. A., de Haan, J. F., and Stammes, P.: A database of spectral surface reflectivity in the range $335-772 \mathrm{~nm}$ derived from 5.5 years of GOME observations, J. Geophys. Res.-Atmos., 108, 4070, doi:4010.1029/2002jd002429, 2003.

Kokhanovsky, A. A., Davis, A. B., Cairns, B., Dubovik, O., Hasekamp, O. P., Sano, I., Mukai, S., Rozanov, V. V., Litvinov, P., Lapyonok, T., Kolomiets, I. S., Oberemok, Y. A., Savenkov, 
S., Martin, W., Wasilewski, A., Di Noia, A., Stap, F. A., Rietjens, J., Xu, F., Natraj, V., Duan, M., Cheng, T., and Munro, R.: Space-based remote sensing of atmospheric aerosols: The multiangle spectro-polarimetric frontier, Earth-Sci. Rev., 145, 85-116, 2015.

Lee, J., Kim, J., Song, C. H., Kim, S. B., Chun, Y., Sohn, B. J., and Holben, B. N.: Characteristics of aerosol types from AERONET sunphotometer measurements, Atmos. Environ., 44, 3110-3117, 2010a.

Lee, J., Kim, J., Song, C. H., Ryu, J. H., Ahn, Y. H., and Song, C. K.: Algorithm for retrieval of aerosol optical properties over the ocean from the Geostationary Ocean Color Imager, Remote Sens. Environ., 114, 1077-1088, 2010 b.

Lee, J., Kim, J., Yang, P., and Hsu, N. C.: Improvement of aerosol optical depth retrieval from MODIS spectral reflectance over the global ocean using new aerosol models archived from AERONET inversion data and tri-axial ellipsoidal dust database, Atmos. Chem. Phys., 12, 7087-7102, doi:10.5194/acp-12-70872012, 2012.

Lee, J., Hsu, N. C., Bettenhausen, C., and Sayer, A. M.: Retrieval of aerosol optical depth under thin cirrus from MODIS: Application to an ocean algorithm, J. Geophys. Res.-Atmos., 118, 1011110124, 2013.

Lee, J., Kim, J., and Lee, Y. G.: Simultaneous retrieval of aerosol properties and clear-sky direct radiative effect over the global ocean from MODIS, Atmos. Environ., 92, 309-317, 2014.

Levy, R. C., Remer, L. A., Mattoo, S., Vermote, E. F., and Kaufman, Y. J.: Second-generation operational algorithm: Retrieval of aerosol properties over land from inversion of Moderate Resolution Imaging Spectroradiometer spectral reflectance, J. Geophys. Res.-Atmos., 112, D13211, doi:13210.11029/12006jd007811, 2007.

Levy, R. C., Remer, L. A., Kleidman, R. G., Mattoo, S., Ichoku, C., Kahn, R., and Eck, T. F.: Global evaluation of the Collection 5 MODIS dark-target aerosol products over land, Atmos. Chem. Phys., 10, 10399-10420, doi:10.5194/acp-10-10399-2010, 2010.

Levy, R. C., Mattoo, S., Munchak, L. A., Remer, L. A., Sayer, A. M., Patadia, F., and Hsu, N. C.: The Collection 6 MODIS aerosol products over land and ocean, Atmos. Meas. Tech., 6, 29893034, doi:10.5194/amt-6-2989-2013, 2013.

Li, R. R., Kaufman, Y. J., Gao, B. C., and Davis, C. O.: Remote sensing of suspended sediments and shallow coastal waters, IEEE T. Geosci. Remote, 41, 559-566, 2003.

Mayer, B. and Kylling, A.: Technical note: The libRadtran software package for radiative transfer calculations - description and examples of use, Atmos. Chem. Phys., 5, 1855-1877, doi:10.5194/acp-5-1855-2005, 2005.

Mishchenko, M. I., Travis, L. D., Kahn, R. A., and West, R. A.: Modeling phase functions for dustlike tropospheric aerosols using a shape mixture of randomly oriented polydisperse spheroids, J. Geophys. Res.-Atmos., 102, 16831-16847, 1997.

Munchak, L. A., Levy, R. C., Mattoo, S., Remer, L. A., Holben, B. N., Schafer, J. S., Hostetler, C. A., and Ferrare, R. A.: MODIS 3 $\mathrm{km}$ aerosol product: applications over land in an urban/suburban region, Atmos. Meas. Tech., 6, 1747-1759, doi:10.5194/amt-61747-2013, 2013.

O’Neill, N. T., Eck, T. F., Smirnov, A., Holben, B. N., and Thulasiraman, S.: Spectral discrimination of coarse and fine mode optical depth, J. Geophys. Res.-Atmos., 108, 4559, doi:10.1029/2002jd002975, 2003.

Park, M. E., Song, C. H., Park, R. S., Lee, J., Kim, J., Lee, S., Woo, J.-H., Carmichael, G. R., Eck, T. F., Holben, B. N., Lee, S.-S., Song, C. K., and Hong, Y. D.: New approach to monitor transboundary particulate pollution over Northeast Asia, Atmos. Chem. Phys., 14, 659-674, doi:10.5194/acp-14-659-2014, 2014.

Redemann, J., Masonis, S. J., Schmid, B., Anderson, T. L., Russell, P. B., Livingston, J. M., Dubovik, O., and Clarke, A. D.: Clearcolumn closure studies of aerosols and water vapor aboard the NCAR C-130 during ACE-Asia, 2001, J. Geophys. Res.-Atmos., 108, 8655, doi:10.1029/2003JD003442, 2003.

Reid, J. S., Hobbs, P. V., Ferek, R. J., Blake, D. R., Martins, J. V., Dunlap, M. R., and Liousse, C.: Physical, chemical, and optical properties of regional hazes dominated by smoke in Brazil, J. Geophys. Res.-Atmos., 103, 32059-32080, 1998.

Remer, L. A., Kaufman, Y. J., Tanré, D., Mattoo, S., Chu, D. A., Martins, J. V., Li, R. R., Ichoku, C., Levy, R. C., Kleidman, R. G., Eck, T. F., Vermote, E., and Holben, B. N.: The MODIS Aerosol Algorithm, Products, and Validation, J. Atmos. Sci., 62, 947-973, 2005.

Remer, L. A., Kleidman, R. G., Levy, R. C., Kaufman, Y. J., Tanre, D., Mattoo, S., Martins, J. V., Ichoku, C., Koren, I., Yu, H. B., and Holben, B. N.: Global aerosol climatology from the MODIS satellite sensors, J. Geophys. Res.-Atmos., 113, D14s07, doi:10.1029/2007jd009661, 2008.

Saide, P. E., Kim, J., Song, C. H., Choi, M., Cheng, Y. F., and Carmichael, G. R.: Assimilation of next generation geostationary aerosol optical depth retrievals to improve air quality simulations, Geophys. Res. Lett., 41, 9188-9196, 2014.

Sayer, A. M., Hsu, N. C., Bettenhausen, C., Ahmad, Z., Holben, B. N., Smirnov, A., Thomas, G. E., and Zhang, J.: SeaWiFS Ocean Aerosol Retrieval (SOAR): Algorithm, validation, and comparison with other data sets, J. Geophys. Res.-Atmos., 117, D03206, doi:10.1029/2011JD016599, 2012.

Sayer, A. M., Hsu, N. C., Bettenhausen, C., and Jeong, M. J.: Validation and uncertainty estimates for MODIS Collection 6 "Deep Blue" aerosol data, J. Geophys. Res.-Atmos., 118, 7864-7872, 2013.

Schmid, B., Hegg, D. A., Wang, J., Bates, D., Redemann, J., Russell, P. B., Livingston, J. M., Jonsson, H. H., Welton, E. J., Seinfeld, J. H., Flagan, R. C., Covert, D. S., Dubovik, O., and Jefferson, A.: Column closure studies of lower tropospheric aerosol and water vapor during ACE-Asia using airborne Sun photometer and airborne in situ and ship-based lidar measurements, J. Geophys. Res.-Atmos., 108, 8656, doi:10.1029/2002JD003361, 2003.

Torres, O., Bhartia, P. K., Herman, J. R., Ahmad, Z., and Gleason, J.: Derivation of aerosol properties from satellite measurements of backscattered ultraviolet radiation: Theoretical basis, J. Geophys. Res.-Atmos., 103, 17099-17110, 1998.

Torres, O., Tanskanen, A., Veihelmann, B., Ahn, C., Braak, R., Bhartia, P. K., Veefkind, P., and Levelt, P.: Aerosols and surface UV products from Ozone Monitoring Instrument observations: An overview, J. Geophys. Res.-Atmos., 112, D24S47, doi:10.1029/2007jd008809, 2007.

Torres, O., Jethva, H., and Bhartia, P. K.: Retrieval of Aerosol Optical Depth above Clouds from OMI Observations: Sensitivity Analysis and Case Studies, J. Atmos. Sci., 69, 1037-1053, 2012. 
Urm, Y.-D. and Sohn, B.-J.: Estimation of aerosol optical thickness over east asia using GMS-5 visible channel measurements, J. Atmosphere, 15, 203-211, 2005.

von Hoyningen-Huene, W., Freitag, M., and Burrows, J. B.: Retrieval of aerosol optical thickness over land surfaces from topof-atmosphere radiance, J. Geophys. Res.-Atmos., 108, 8657, doi:10.1029/2001JD002018, 2003.

von Hoyningen-Huene, W., Yoon, J., Vountas, M., Istomina, L. G., Rohen, G., Dinter, T., Kokhanovsky, A. A., and Burrows, J. P.: Retrieval of spectral aerosol optical thickness over land using ocean color sensors MERIS and SeaWiFS, Atmos. Meas. Tech., 4, 151-171, doi:10.5194/amt-4-151-2011, 2011.

Wang, J., Christopher, S. A., Brechtel, F., Kim, J., Schmid, B., Redemann, J., Russell, P. B., Quinn, P., and Holben, B. N.: Geostationary satellite retrievals of aerosol optical thickness during ACE-Asia, J. Geophys. Res.-Atmos., 108, 8657, doi:10.1029/2003JD003580, 2003.

Xu, J.-W., Martin, R. V., van Donkelaar, A., Kim, J., Choi, M., Zhang, Q., Geng, G., Liu, Y., Ma, Z., Huang, L., Wang, Y., Chen, H., Che, H., Lin, P., and Lin, N.: Estimating ground-level $\mathrm{PM}_{2.5}$ in eastern China using aerosol optical depth determined from the GOCI satellite instrument, Atmos. Chem. Phys., 15, 1313313144, doi:10.5194/acp-15-13133-2015, 2015.

Yoon, J., von Hoyningen-Huene, W., Vountas, M., and Burrows, J. P.: Analysis of linear long-term trend of aerosol optical thickness derived from SeaWiFS using BAER over Europe and South China, Atmos. Chem. Phys., 11, 12149-12167, doi:10.5194/acp11-12149-2011, 2011.
Yoon, J., von Hoyningen-Huene, W., Kokhanovsky, A. A., Vountas, M., and Burrows, J. P.: Trend analysis of aerosol optical thickness and Ångström exponent derived from the global AERONET spectral observations, Atmos. Meas. Tech., 5, 12711299, doi:10.5194/amt-5-1271-2012, 2012.

Yoon, J., Burrows, J. P., Vountas, M., von Hoyningen-Huene, W., Chang, D. Y., Richter, A., and Hilboll, A.: Changes in atmospheric aerosol loading retrieved from space-based measurements during the past decade, Atmos. Chem. Phys., 14, 68816902, doi:10.5194/acp-14-6881-2014, 2014.

Yoon, J. M., Kim, J., Lee, J. H., Cho, H. K., Sohn, B. J., and Ahn, M. H.: Retrieval of Aerosol Optical Depth over East Asia from a Geostationary Satellite, MTSAT-1R, Asia-Pac, J. Atmos. Sci., 43, 133-142, 2007.

Zhang, H., Lyapustin, A., Wang, Y., Kondragunta, S., Laszlo, I., Ciren, P., and Hoff, R. M.: A multi-angle aerosol optical depth retrieval algorithm for geostationary satellite data over the United States, Atmos. Chem. Phys., 11, 11977-11991, doi:10.5194/acp11-11977-2011, 2011. 